\title{
From submarine to subaerial outofsequence thrusting and gravitydriven extensional faulting: Gran Sasso Massif, Central Apennines, Italy
}

DOI:

10.1029/2019TC005783

\section{Document Version}

Accepted author manuscript

Link to publication record in Manchester Research Explorer

Citation for published version (APA):

Lucca, A., Storti , F., Balsamo, F., Clemenzi, L., Fondriest, M., Burgess, R., \& di Toro, G. (2019). From submarine to subaerial outofsequence thrusting and gravitydriven extensional faulting: Gran Sasso Massif, Central Apennines, Italy. Tectonics. https://doi.org/10.1029/2019TC005783

\section{Published in:}

Tectonics

\section{Citing this paper}

Please note that where the full-text provided on Manchester Research Explorer is the Author Accepted Manuscript or Proof version this may differ from the final Published version. If citing, it is advised that you check and use the publisher's definitive version.

\section{General rights}

Copyright and moral rights for the publications made accessible in the Research Explorer are retained by the authors and/or other copyright owners and it is a condition of accessing publications that users recognise and abide by the legal requirements associated with these rights.

\section{Takedown policy}

If you believe that this document breaches copyright please refer to the University of Manchester's Takedown Procedures [http://man.ac.uk/04Y6Bo] or contact uml.scholarlycommunications@manchester.ac.uk providing relevant details, so we can investigate your claim.

\section{OPEN ACCESS}


Lucca Alessio (Orcid ID: 0000-0001-6859-2098)

Storti Fabrizio (Orcid ID: 0000-0003-2809-9471)

Balsamo Fabrizio (Orcid ID: 0000-0003-1931-466X)

Fondriest Michele (Orcid ID: 0000-0001-5114-810X)

Burgess Ray (Orcid ID: 0000-0001-7674-8718)

Di Toro Giulio (Orcid ID: 0000-0002-6618-3474)

\section{From submarine to subaerial out-of-sequence thrusting and gravity-driven extensional faulting: Gran Sasso Massif, Central Apennines, Italy}

Alessio Lucca ${ }^{1}$, Fabrizio Storti ${ }^{1}$, Fabrizio Balsamo ${ }^{1}$, Luca Clemenzi ${ }^{{ }^{*}}$, Michele Fondriest ${ }^{2}$, Ray Burgess ${ }^{2}$, and Giulio Di Toro ${ }^{3,4}$

1 - NEXT - Natural and Experimental Tectonics research group, Department of Chemistry, Life Sciences and Environmental Sustainability, University of Parma, I-43124 Parma, Italy

2 - School of Earth and Environmental Sciences, University of Manchester, Oxford Road, Manchester M13 9PL, UK

3 - Dipartimento di Geoscienze, Università degli Studi di Padova, Via Giovanni Gradenigo, 6, 35131 Padova, Italy

4 - Istituto Nazionale di Geofisica e Vulcanologia, Via di Vigna Murata, 605, 00143 Roma RM, Italy

* - Now at ENI S.p.A, Upstream and Technical Services - San Donato Milanese, Italy

Corresponding Author Details

E-mail: alessio.lucca@studenti.unipr.it

Telephone number: +393931323420

This article has been accepted for publication and undergone full peer review but has not been through the copyediting, typesetting, pagination and proofreading process which may lead to differences between this version and the Version of Record. Please cite this article as doi: 10.1029/2019TC005783 


\section{Abstract}

Thrust wedges evolution is typically characterized by out-of-sequence thrusting, which can occur both in submarine and subaerial conditions to maintain the balance between gravitational and tectonic forces. The Gran Sasso Massif, in Central Italy, is a high topography region where the kinematics and environmental conditions of deformation of some fault zones are still controversial, and this bears important implications for the Central Apennines orogenic wedge evolution. To obtain further constraints on fault activity in the Gran Sasso Massif, we studied the Monte Camicia and Vado di Ferruccio thrusts using structural, petrographical and geochemical analyses. Such dataset allowed us to constrain the structuraldiagenetic evolution of the studied faults, which has first-order implications in the characterization of their paleo-hydraulic properties.

Our results indicate that in the Vado di Ferruccio out-of-sequence thrust, pressure solution-mediated mass transfer promoted low-permeability conditions in the fault core that led to a semi-closed fluid circulation, pore fluid overpressuring, and dolomite crystallization in submarine conditions. In contrast, the Monte Camicia outof-sequence thrust was characterized by dominant cataclasis in subaerial conditions, which facilitated meteoric fluid infiltration. By considering both fault zones as belonging to the same thrust system at crustal scale, we interpret these differences as indicating the occurrence of multiple pulses of thrusting during the exhumation of this sector of the Central Apennines, up to Quaternary times, when extensional faulting eventually dissected the thrust stack. This caused extensional reactivation of the Monte Camicia Thrust and related alteration in vadose zone conditions, leading to porosity enhancement, dolomite dissolution and calcitization. 


\section{Introduction}

Crustal accretion in thrust wedges typically occurs by the concomitant nucleation of new faults at the wedge toe (in-sequence or piggyback thrusting) and deformation rejuvenation in the hinterland (out-of-sequence or break-back thrusting; e.g. Butler, 1987) to ensure the mechanical balance of thrust wedges by systematically re-adjusting surface tapers (e.g. Davis et al. 1983; Dahlen, 1990). This implies coeval activity of thrust faults in different sectors of orogens (e.g. Verges \& Muñoz, 1990; Boyer, 1992), as also indicated by experimental modelling, where new thrusts nucleate at wedge toes in a piggyback fashion and then remain active during their incorporation within tectonic wedges (e.g. Storti et al., 2000; Konstantinovskaya \& Malavieille, 2005; Cruz et al., 2010; Graveleau et al., 2012; Granado \& Ruh, 2019). Synkinematic sediments preserved in thrust footwalls typically record fault activity in foreland basin systems (De Celles and Giles, 1996), whereas the sedimentary signature of thrust motion is scarce in sub-aerial erosional environments and this may have contributed to underestimates of out-of-sequence thrusting in mountain belts. Low temperature thermochronology techniques provide useful tools to make inferences on thrust activity exhuming rocks in the interior of mountain belts (e.g. Donelick et al., 2005), and $\mathrm{K}-\mathrm{Ar}$ isotopic dating of synkinematic/authigenic illite helps to constrain fault activity in crystalline rocks (Viola et al., 2016). However, applicability of these techniques in carbonate massifs deformed at very shallow crustal conditions is limited, and uranium-series isotopic dating of calcite (e.g. Rasbury and Cole, 2009) is not yet developed to be a routine tool. For these reasons, coupling structural geology and diagenesis still provides a useful and well-proven tool to investigate fault activity, including the environmental conditions of deformation (e.g. Laubach et al., 2010).

Exhumed field analogues have long been studied to investigate the interaction between fault zone and paleofluid evolution (Ghisetti et al., 2001; Kirschner \& Kennedy, 2001; Agosta \& Kirschner, 2003; Bussolotto et al., 2007; Agosta et al., 2008; Breesch et al., 2009; Hausegger et al., 2010; Clemenzi et al., 2015; Balsamo et al., 2016; Smeraglia et al., 2016; Lucca et al., 2019). Applying a range of different geochemical techniques provides a holistic approach to understand the structural diagenetic evolution in the context of fluid-rock interaction processes, fluid migration pathways and fluid sources (Burkhard \& Kerrich, 1988; Roure et al., 2005; Laubach 
\& Ward, 2006; Vilasi et al., 2009; Wiltschko et al., 2009; Dewever et al., 2010; Cooley et al., 2011; Ferket et al., 2011; Mozafari et al., 2017). The oxygen stable isotopes ratios of cements depend mainly on compositions and precipitation temperatures of fluids, whereas carbon stable isotope ratios depend on the sources of $\mathrm{CO}_{2}$ in fluids (Friedman \& O'Neil, 1977; Hoefs, 1997). Therefore, carbon and oxygen stable isotope ratios are commonly combined to identify the diagenetic environment of cements (Allan \& Matthews, 1977; Hudson, 1977; Banner \& Hanson, 1990; Nelson \& Smith, 1996). Strontium geochemistry is particularly used in carbonate rocks for stratigraphic and diagenetic studies, as a proxy for age correlations and for fluid-rock interaction processes (Burke et al., 1982; Emery \& Robinson, 1993). The strontium isotopes ratio of the cements directly records that of the cementing fluid (Banner, 1995; McArthur et al., 2012). Noble gases isotopes are used to determine the source of volatile elements trapped in minerals, and can discriminate between groundwaters that have equilibrated with atmospheric gases $\left({ }^{36} \mathrm{Ar}\right)$, crustal fluids recording isotope $\left({ }^{4} \mathrm{He},{ }^{40} \mathrm{Ar}\right)$ formed by radiogenic decay, or from magmatic fluids containing a mantle-derived component of noble gases $\left({ }^{3} \mathrm{He}\right.$; Ballentine \& Burnard, 2002; Ballentine et al., 2002).

Here we used structural diagenesis to provide additional constraints on fault activity in the Gran Sasso Massif of the Central Apennines (Figs. 1A-B), where outstanding exposures of both thrust and extensional fault zones affecting limestones and dolostones are available (e.g. Ghisetti and Vezzani, 1991; D'Agostino et al., 1998; Cardello and Doglioni, 2014; Pace and Calamita, 2015; Demurtas et al., 2016). Despite several structural studies in the Gran Sasso Massif, significant uncertainty remains on the first-order structural architecture of the area, which is characterized by high sedimentary and structural complexity (e.g. Cardello \& Doglioni, 2015, and references therein). Low-angle fault zones outcropping along the footwall of the Campo Imperatore extensional fault system and juxtaposing Jurassic rocks onto Triassic ones (Figs. 2A-B), have been alternatively interpreted as belonging to: (i) a Mesozoic extensional fault system passively rotated during folding and thrusting (Pace et al., 2014; Pace \& Calamita, 2015); (ii) a Pliocene out-ofsequence thrust system (Ghisetti \& Vezzani, 1986, 1991; Ghisetti, 1987); or (iii) a Pleistocene post-orogenic extensional fault system (D’Agostino et al., 1998; Fig. 3). Deciphering whether this low-angle fault system had contractional or extensional 
kinematics, and the chronological relationships with the underlying Vado di Ferruccio Thrust (Leah et al., 2018; named Upper Thrust in Cardello \& Doglioni, 2015, and in Pace \& Calamita, 2015), has important implications for understanding the NeogeneQuaternary evolution of the Central Apennines thrust wedge and the environmental conditions of deformation.

In this contribution, detailed field mapping was combined with structural, petrographical and geochemical analyses to understand the paleofluid evolution in the Monte Camicia and Vado di Ferruccio thrusts. Syntectonic cements were analyzed through optical and cold cathodoluminescence microscopy, carbon, oxygen, strontium and noble gas isotope geochemistry. Our data support thrust kinematics at shallow burial depths for the low-angle fault zones outcropping in the footwall of the Campo Imperatore extensional fault system, hereafter named Monte Camicia Thrust. This thrust system was then overprinted by gravitationally-induced late-stage extension, which had also a minor effect on the Vado di Ferruccio Thrust. Petrographic and geochemical data indicate that the Monte Camicia and Vado di Ferruccio thrusts, despite being sub-parallel and separated by only few hundred meters thick thrust sheet (Figs. 1B and 2), had a completely different structural diagenetic evolution characterized by different deformation mechanisms, timing, and permeability architecture of the fault zones. This is despite being interpreted as belonging to the same thrust system at the crustal scale (Ghisetti et al., 1991). In both cases, the signature of fluids preserved in calcite veins does not show contamination by basement- and mantle-derived sources.

\section{Geological Framework of the Central Apennines}

The Apennines fold-and-thrust belt is a segment of the Alpine-Himalayan orogeny that grew in Neogene times from the westward subduction and rollback of the Adria microplate underneath the Eurasia plate (e.g. Principi and Treves, 1984; Malinverno and Ryan, 1986; Royden, 1988; Dewey et al., 1989; Patacca et al., 1990; Doglioni, 1991; Royden \& Faccenna, 2018). The evolution of the Central Apennines thrust wedge progressed by telescoping of the Triassic to Cretaceous Adria passive margin carbonate sedimentary succession, which is characterized by important lateral facies variations between the Lazio-Abruzzi platform to the south, and the 
Umbria-Marche basin to the north (Figs. 1B-C, e.g., Colacicchi \& Praturlon, 1965; Accordi \& Carbone, 1986; Ciarapica \& Passeri, 1998; Cosentino et al., 2010). In particular, the latter is characterized by thick Upper Triassic evaporites, which do not occur in the former, where poorly layered platform limestone dominates (Adamoli et al., 1990; Ciarapica, 1990; Ciarapica, 2007; Cosentino et al., 2010). Evidence for a Mesozoic complex syn-rift extensional tectono-sedimentary architecture is widespread in the Central Apennines and typically consists of horst-and-graben patterns generally sealed by the Upper Jurassic-Lower Cretaceous post-rift Maiolica formation (Centamore et al., 1975; Castellarin et al., 1978; Cosentino \& Parotto, 1986; Santantonio, 1993; Pierantoni et al., 2013). The carbonate succession exposed in the Gran Sasso Massif preserves the paleogeographic transition between the Lazio-Abruzzi platform and the Umbria-Marche basin (Figs. 1B-C; Fig. 2C; Ciarapica, 1990; Ghisetti \& Vezzani, 1991; Ciarapica \& Passeri, 1998), and includes superb examples of Jurassic faulting (e.g., Cardello \& Doglioni, 2015).

Synorogenic siliciclastic sediments constrain the onset of thrusting in the south-westward sector of the Central Apennines to the Late Tortonian, up to early Pliocene times in the Gran Sasso Massif (Ghisetti \& Vezzani, 1991; Ghisetti et al., 1993b; Cipollari \& Cosentino, 1995; Cipollari et al., 1999; Centamore \& Rossi, 2009). Thrust nucleation occurred in-sequence by overall north-eastward piggyback accretion, and was overprinted by out-of-sequence thrusting (Bally et al., 1986; Cavinato et al., 1994; Cipollari \& Cosentino, 1995; Sani et al., 2004; Billi et al., 2006; Cosentino et al., 2010; Carminati et al., 2014; Smeraglia et al., 2019), which is strongly evident in the Gran Sasso Massif (Ghisetti \& Vezzani, 1986, 1991), where the arc-shaped frontal thrust trending E-W in the western sector and N-S in the eastern one (Fig. 1B) resulted from the combined effects of both re-activation of the Mesozoic tectono-sedimentary extensional inheritance (Castellarin et al., 1978; Galluzzo \& Santantonio, 2002; Scisciani et al., 2002; Calamita et al., 2003; Cardello \& Doglioni, 2015) and syn-orogenic block rotations about their vertical axes (Dela Pierre et al., 1992; Mattei et al., 1995; Speranza et al., 2003; Satolli et al., 2005). 
Intramontane basins started developing in the Central Apennines since late Pliocene times, associated with NW-SE trending high-angle extensional faulting that dissected the previously formed contractional architecture (e.g. Cavinato \& DeCelles, 1999; Ghisetti \& Vezzani, 1999; D’Agostino et al., 2001; Cosentino et al., 2017). In particular, a major extensional pulse occurred at about $2 \mathrm{Ma}$ and promoted uplift and widespread erosion, and the reorganization of the drainage systems (Bartolini et al., 2003; Centamore \& Nisio, 2003; Galadini et al., 2003; Ascione et al., 2008; Cosentino et al., 2017).

The crustal structure of the Central Apennines is still a matter of debate and both thin- and thick-skinned tectonic styles have been proposed (Bally et al., 1986; Calamita e Deiana, 1988; Sage et al., 1991; Ghisetti et al., 1993a; Chiarabba and Amato, 1996; Barchi et al., 1998; Doglioni et al., 1998; Liotta et al., 1998; Patacca et al., 2008). According to Tozer et al. (2002), deformation rates obtained from balanced cross-sections, where the crystalline basement is involved, provide more reasonable results compared to estimates from thin-skinned tectonic models. This adds to the Moho depth underneath the belt, which approaches $50 \mathrm{~km}$ (Mele et al., 2006; Di Luzio et al., 2009), thus suggesting thick-skin tectonics. However, the two contrasting models may not be alternative end-member solutions because the depthto-décollement typically shallows forelandward in thrust wedges (Davis et al., 1983; Dahlen et al., 1984). In the Apennines, the presence of thick Triassic evaporites in the basinal succession has favoured mechanical decoupling between deformation in the cover sediments and in the crystalline basement (Davis \& Engelder, 1985; Graveleau et al., 2012), which contractional deformation features are documented only westward of the axial zone of the thrust belt (Tiberti et al., 2005; Di Luzio et al., 2009).

The environmental conditions of deformation in the Central Apennines have been constrained by vitrinite reflectance studies, apatite fission track thermochronology, fluid inclusion microthermometry, and stable isotope geochemistry (Corrado, 1995; Ghisetti et al., 2001; Murgia et al., 2004; Rusciadelli et al., 2005; Agosta et al., 2008; Ronchi et al., 2010; Smeraglia et al., 2016). Thermochronological modelling suggests that the maximum burial depth of the exposed carbonate successions never exceeded $4 \mathrm{~km}$, at temperatures lower than about $100{ }^{\circ} \mathrm{C}$, indicating a geothermal gradient of about $20{ }^{\circ} \mathrm{C} / \mathrm{km}$. Moreover, 
modelling results show that the burial history of the Adria passive margin successions was characterized by two burial and exhumation episodes, related to the passive margin and the foredeep stages, respectively (Rusciadelli et al., 2005).

\section{Structural Setting of the Study Area}

The following summary description is based largely on geological mapping and structural analysis performed in the area by F. Ghisetti \& L. Vezzani (1986; $1991 ; 1997)$. The first-order structural architecture of the Gran Sasso Massif consists of three vertically stacked thrust sheets (TS1, TS2 and TS3), lying in the hanging wall of the Gran Sasso Frontal Thrust and separated, from bottom to top, by the Vado di Ferruccio and Monte Camicia thrusts, respectively (Figs. 2, 3). Overturned, E-W striking, anticlines and synclines involving the Lower Jurassic to Messinian sedimentary succession characterize the TS3 thrust sheet in the hanging wall of the Gran Sasso Frontal Thrust (Figs. 2B-C). These folds are decapitated by the out-ofsequence, convex-upward Vado di Ferruccio Thrust (Fig. 2B). The hanging wall of the latter consists of Upper Triassic Bituminous dolostones to Miocene calcarenites, mostly arranged in a NNE-dipping monocline (TS2; Figs. 2A-B-C). At the top of the stack, the hanging wall of the Monte Camicia thrust consists of $\mathrm{N}$-dipping Upper Triassic dolostones to Paleogene marly limestones and marls, and is characterized by an array of subsidiary thrusts dissecting the overall monocline geometry (TS1; Figs. 2A-B-C). The tectonic juxtaposition of younger-on-older rocks, indicates again an out-of-sequence chronology.

The Campo Imperatore extensional fault system (e.g. Demurtas et al., 2016) has an estimated maximum downthrow of about 2000 m (Servizio Geologico d'Italia, 1963) and consists of an array of E-W to NW-SE striking high-angle fault zones bounded to the north by the Campo Imperatore intermontane basin (Figs. 1B, 2A; e.g. Ghisetti and Vezzani, 1986). The latter is filled by fluvio-glacial Quaternary deposits affected by unequivocal extensional deformations (Giraudi \& Frezzotti, 1997; Galadini \& Messina, 2004). 


\section{Methodology}

A total of 1480 structural data were collected at thirty-nine structural sites, along the Monte Camicia and Vado di Ferruccio thrusts. Data from the latter are summarized from Leah et al. (2018). Mesostructural analysis was performed to define faulting related deformation structures, their cross cutting relationships, orientation and kinematics. 101 thin sections were cut from 61 rock specimens sampled in the thrust cores and damage zones, and in the protoliths unaffected by faulting-related deformations. Samples were stained with Alizarin Red $S$ and potassium ferricyanide to discriminate the different carbonate minerals including calcite and dolomite and their iron-rich equivalents (Dickson, 1966) and thin sections were used for standard, cathodoluminescence and electronic microscopy. Petrographic analysis allowed us to characterize the diagenetic modification, specifically the syntectonic cement types and their mineralogy. Following petrography, oxygen and carbon stable isotope ratios were determined on 94 selected samples of limestone and dolostone host rocks and cements to decipher diagenetic fluid sources and fluid-rock interaction processes. Moreover, fluid inclusion petrography and microthermometry were carried out on 8 doubly-polished thin sections (wafers) to constrain fluid temperature and salinity. Eventually, strontium and noble gas isotopes analyses, respectively, were performed on 8 and 12 sub-samples of host rocks and cements to investigate possible fluid contributions from the metamorphic basement and/or the mantle. Details on analyses procedures and instruments are reported in the Supplementary material $\left(\mathrm{SMn}^{\circ}\right.$ ?).

\section{Contractional Structural Architecture}

The mapped fault pattern and contractional structural data are illustrated in Fig. 4. The map indicates that the Monte Camicia Thrust is a complex fault system consisting of a basal master slip surface ( $\phi_{1}$ to $\phi_{4}$ in Ghisetti and Vezzani, 1986) mostly placing northward-dipping Jurassic to Cretaceous bioclastic limestones onto northeastward-dipping Upper Triassic Bituminous dolostones and Lower Jurassic massive dolostones at the footwall. Two main splay thrusts ( $\phi_{3}$ and $\phi_{2}$ in Ghisetti and Vezzani, 1986) emanate from the basal one, near Mt. Camicia and to the south-west respectively (Figs. 5A, B). Overall, this thrust array can be described as an out-ofsequence structure characterized by a strong lateral variability. 
The Monte Camicia Thrust basal master slip surface strikes WSW-ENE in the Le Veticole area to the west (sites CF26), E-W near the summit of Mt. Camicia (sites CF16 and CF17) and in the klippe to the east (sites CF22 and CF23), and again WSW-ENE to the east of Colle dell'Omo Morto (site CF18; Fig. 4). Tectonic transport directions provided by S-C like arrays of compactional and shear surfaces are typically to the north (Fig. 6). However, in the Le Veticole area the tectonic transport direction is towards the north-west (Fig. 5C). In the Miniera di Lignite tectonic window, fault geometry shows a higher variability, from WNW-ESE strike (sites CF3, CF7, CF8 and CF9) to E-W (sites CF5 and CF11), up to WSW-ENE (site CF10), SW-NE (site CF12) and almost N-S (site CF13). Despite such a variability, tectonic transport directions are constantly to the north, apart from sites CF7, CF8 and CF9, where the shear sense is towards NNE (Fig. 5C). This implies that NNE-SSW to N-S faults attain a left-lateral transpressional (site CF12) to almost strike-slip (site CF13) kinematics (Fig. 5D). As a consequence, the basal thrust sheet in this area pinches out towards the east and attains a lensoidal shape (Fig. 5E). Structural data on the splay thrust near the summit of Mt. Camicia (site CF20) indicates a northward transport direction (Fig. 5C).

Structural data from the Vado di Ferruccio Thrust are synthetically illustrated in Fig. 4 and show that the master slip surface strikes almost E-W and dips southward, apart from sites VF8 and VF10 where it attains a NW-SE strike and a south-westward dip. The fault zone is characterized by well-developed S-C-C' structural fabrics (Figs. 7A-D) indicating significant variability in the tectonic transport direction, ranging from top to the NW in the southwestern sector of the Fornaca tectonic window, up to top to the NE in the southeastern sector. Folding in the footwall damage zone is common and poles to fold limbs describe N-S girdles (Leah et al., 2018).

In summary, cumulative analysis of structural data collected along the Monte Camicia Thrust indicates that the mean strike of the master slip surface is $092^{\circ}$ and the mean dip is $33^{\circ}$ to the S. Slickenlines mean rake is $008^{\circ} 35^{\circ}$, with a northward tectonic transport direction, as indicated by pressure solution surfaces in the thrust damage zones, which strike $109^{\circ}$ and dip $68^{\circ}$ southward (Fig. 8). Cumulative analysis of structural data collected along the Vado di Ferruccio Thrust show two main clusters oriented $083^{\circ} 24^{\circ}$ and $088^{\circ} 48^{\circ}$, respectively. Slickenlines have a mean rake of $037^{\circ} 39^{\circ}$ and dip to the south. Pressure solution surfaces in the thrust 
damage zone have quite variable orientations, with three main maxima, at $138^{\circ} 40^{\circ}$, $130^{\circ} 80^{\circ}$ and $090^{\circ} 70^{\circ}$, respectively.

\section{Extensional Structural Architecture}

The extensional fault pattern is best expressed in the southern part of the study area and consists of E-W to NW-SE striking, high-angle fault zones dipping either northward or southward and overprinting the contractional pattern (Fig. 9). In the Fornaca valley, the Vado di Ferruccio Thrust is dissected by two extensional fault zones striking WNW-ESE (site VF2) and NW-SE (site VF6; Fig. 7C), respectively. Structural data indicate dip-slip motion in both cases, as well as at other sites in the hanging wall (VF4, VF9 and VF10) and in the footwall (VF8). At sites VF3 and VF5, low-displacement high-angle extensional faults sole down into the master slip surface of the Vado di Ferruccio Thrust (Figs. 7A, B).

Evidence for negative inversion of the contractional architecture is widespread along the Monte Camicia Thrust. Subsidiary extensional faults are abundant in the hanging wall of the basal master slip surface to the west of Mt. Camicia and flatten down into it. Near horizontal tectonic stylolites occur mainly in the footwall of the thrust (site CF17; Fig. 10A). A similar geometric and kinematic array occurs along a subsidiary thrust splay showing extensional re-activation kinematics, at site CF14, in the hanging wall (Fig 9). Near the westward boundary of the study area, extensional reactivation of the basal master slip surface produced abundant shallow dipping compactional surfaces in the footwall damage zone (Fig. 10B). Exposures of the Monte Camicia Thrust in the Miniera di Lignite tectonic window preserve evidence for both the extensional reactivation of the master slip surface (site CF10), and its offsetting by a high angle extensional fault zone (sites CF3, 4, 5). It is worth noting that intense jointing and proto-brecciation affects the rocks in the footwall of this fault zone (Fig. 10C). A similar fabric is well developed on the eastern side of the valley, in the hanging wall of the thrust master slip surface (Fig. 10D).

Summarizing, cumulative structural data analysis indicates that extensional fault zones flattening onto the Vado di Ferruccio Thrust have a mean orientation of $088^{\circ} 80^{\circ}$ with slickenlines oriented $199^{\circ} 77^{\circ}$. In contrast, extensional fault zones cutting through the same thrust are oriented $121^{\circ} 85^{\circ}$ with a mean slickenline orientation of $202^{\circ} 82^{\circ}$ (Fig. 11). In the hanging wall of the Monte Camicia Thrust, extensional fault zones flattening onto the main basal slip surface are oriented $095^{\circ}$ 
$74^{\circ}$ with slickenline orientation of $200^{\circ} 70^{\circ}$. In the southern part of the Miniera di Lignite area, extensional fault zones dissecting the thrust are oriented $086^{\circ} 62^{\circ}$ and show slickenlines with a mean orientation of $184^{\circ} 67^{\circ}$.

\section{Structural Diagenetic Features of the Monte Camicia and Vado di Ferruccio Thrust}

\subsection{Monte Camicia Thrust}

The Monte Camicia basal thrust zone is generally composed of a sharp and well-defined principal slip surface overlying a half meter thick, well cemented cataclastic layer juxtaposed to up to 5 meters thick shattered calcarenites in the hanging wall damage zone, onto a 2 to 3 metres-thick footwall damage zone made of strongly deformed dolostones. Rudist calcarenites in the hanging wall damage zone are affected by bedding-parallel burial stylolites and by high-angle south dipping tectonic pressure solution surfaces. Bituminous dolostones in the footwall damage zone are organized in S-C compaction and shear band arrays. The fault core consists of cataclasites and, locally, foliated cataclasites (Figs. 12A-B). Foliation is provided by S-C microarrays of micritic calcite cement and matrix (CFCalSB), separating lensoids of crackle-brecciated dolostones (Woodcock \& Mort, 2008) and dolostone survivor clasts (CFCalDolSB; Fig. 12A; Site CF26), overprinted by extensional shear fractures. Injection veins of finely crystalline dolomitic-calcitic matrix commonly originate at the principal slip surface and propagate into the hanging wall cataclastic material. Moreover, the principal slip surface is locally dilated and cemented by a thin calcite vein (Fig. 12B). Veins dipping gently to the north occur in the footwall of the southward-dipping principal slip surface. They are cemented by non-ferroan, non-equigranular, mosaic calcite crystals (CFCalV), locally interested by Type I twinning of Burkhard (1993), that typically have dimensions lower than about $200 \mu \mathrm{m}$ and show alternating non-luminescent and yellow colours under cathodoluminescence (Figs. 12C-D).

In the Miniera di Lignite area, the thrust zone is characterized by widespread karstification (Sites CF3, CF5-10) affecting cataclastic rocks both on the hanging wall and footwall sides. Horizontal joints, curved planes and alveolar textures are common and indicate a late-stage vadose zone alteration of the fault core (Figs. 12E-F; Goldstein et al., 1991). Karst-related secondary dissolution porosity is 
cemented by dogtooth to mosaic calcite crystals (CFCalP) that show the same alternating cathodoluminescence colours of CFCalV and are also associated with vadose silt, occurring both as geopetal fabrics and as solid inclusions in the cements (Figs. 12E-H; Barker \& Halley, 1988). Subvertical, non-luminescent and non-ferroan calcite veins (BDCalV) occur in Bituminous dolostones in the footwall damage zone (Figs. 12l-J). Qualitative compositional maps highlights that, approaching the principal slip surface, discrete veining is replaced by diffuse stockwork microcracking, dolomite dissolution, and calcite cementation. In proximity of the principal slip surface, both dolostone clasts and calcite cements are affected by dissolution, which leads to higher vuggy porosity (Figs. 13A-C).

\subsection{Vado di Ferruccio Thrust}

The Vado di Ferruccio Thrust is composed of a 0.5 to 2 meter-thick fault core juxtaposing the Bituminous dolostones in the hanging wall, and onto the Corniola in the footwall. The fault core is represented by a foliated cataclasite (VFCore), with SC-C' structure and abundant pressure solution seams (Leah et al., 2018). Dolostones in the hanging wall damage zone show an up to 2 meters-thick zone, characterized by a thrust parallel to low-angle oriented network of fault-veins (sensu Woodcock \& Mort, 2008). The latter are syntaxial and cemented by coarse dolomite crystals (BDDolFV), which display growth competition and become locally saddleshaped (Xenotopic-C of Gregg \& Sibley, 1984) towards the median line (Figs. 14AB). In places, fault-veins are deformed, producing crackle to chaotic breccias (Woodcock \& Mort, 2008; Figs. 14A and 14C). Dolomite crystals infilling veins have the same purple color of the host rock under cathodoluminescence, with the exception of some outer growth zones which display red colours (Fig. 14D). Dolomite crystals in both veins and host rock are non-ferroan. Where dolostones are clay-rich, pressure solution surfaces are well-developed and add to microcracks and faultveins to accommodate deformation (Fig. 14E). Fault-veins and tectonic stylolites in the hanging wall damage zone are associated with microcrystalline silica, which is preferentially located in anastomosed bands, which are parallel to and re-open

pressure solution surfaces. Silica crystal size is typically lower than about $50 \mu \mathrm{m}$ (Figs 13D, F, 14F). High-angle extensional fractures and dilation jogs in dolostones overprint the contractional structures and are cemented by drusy calcite showing 
Type I twinning of Burkhard (1993) and characterized by well-zoned orange to orange-dull colors under cathodoluminescence (VFCal2; Figs. 14G-H).

The footwall damage zone is composed of marly limestones (CoHR) intersected by a dense network of pressure solution surfaces, parallel and at lowangle to the fault core, and by abundant veins (Fig. 15A-D). Stylolite abundance and thickness increases approaching the fault core. Crosscutting relationships and cathodoluminescence observations show that two non-ferroan calcite cements occur in the veins. VFCal1 veins strike parallel to the principal slip surface, are perpendicular to pressure solution surfaces, and mutually crosscut with them, while VFCal2 veins are subvertical and always cut pressure solution seams. VFCal1 veins are generally characterized by mosaic non-equigranular calcite crystals showing dull luminescence, darker than the host rock, whereas VFCal2 veins display an orange color in cathodoluminescence and mosaic to drusy textures (Figs. 15A-D). Some residual porosity in VFCal1 veins was sealed by overgrowths of calcite 2, which typically show lower twinning intensity (Figs. 15E, F). In the Corniola, beddingperpendicular veins infilled by up to $\mathrm{cm}$-size rhombohedric calcite crystals (CoCalV) showing intense Type I twinning of Burkhard (1993), predate both VFCal1 veins and, therefore, out-of-sequence thrusting.

Tectonic solution seams in the fault core include idiotopic-E dolomite crystals (Gregg \& Sibley, 1984) that, under cathodoluminescence, show red-purple cloudy cores and, red and yellow growth zones (Figs. 13l, 15G, H). This indicates that they pertain to a dolomite generation that is different from both the Bituminous dolostones host rocks and dolomite infillings in fault-veins and that post-dates the latter.

\subsection{Fluid inclusions}

Syntectonic cements CFCalV, CFCalP, BDCalV, BDDolFV, VFCal1 and VFCal2 are all inclusion-poor and show rare, less than $10 \mu \mathrm{m}$ in diameter, monophase fluid inclusions (Fig. 16A). These inclusions could not be successfully stretched after several heating-freezing cycles. Therefore, microthermometric measurements of final ice melting temperatures could not be obtained. Nevertheless, fluid inclusions in CFCalV and CFCalP cements associated with the Monte Camicia Thrust are vertically elongated (Fig. 16A). Moreover, CFCalP cement hosts solid silt inclusions (Fig. 16B). These features are typical of calcites that precipitated near 
and/or above the water table, thus indicating they formed in a meteoric phreatic to vadose diagenetic environment (e.g. Goldstein, 1990).

\section{Geochemical data}

8.1 Carbon and oxygen stable isotopes data

Carbon and oxygen stable isotope data are illustrated in a summary plot in $\delta^{13} \mathrm{C}$ vs. $\delta^{18} \mathrm{O}$ in Figure 17A and separately for each of the thrust sheets, (Figs. 17B, C). Analyses results are also reported in Table S1. Rudist calcarenites host rocks, which include bioclasts, detrital and intergranular matrix and cement, in the hanging wall of the Monte Camicia Thrust $(\mathrm{RCHR})$ have $\delta^{18} \mathrm{O}$ values ranging from $-1.76 \%$ to $0.30 \%$ and $\delta^{13} \mathrm{C}$ values between $+1.69 \%$ and $+2.38 \%$ o. In the fault core, calcite cataclastic shear bands (CFCalSB) have $\delta^{18} \mathrm{O}$ values ranging from $-7.53 \%$ to $4.56 \%$ whereas $\delta^{13} \mathrm{C}$ values are between $-2.88 \%$ ond $-0.40 \%$ o. Fault core rocks are shear bands (CFCalDolSB) composed of a mixture of calcite and dolomite and the isotopic data are therefore likely to be mixed signals from these two minerals. $\delta^{18} \mathrm{O}$ values range between $-2.71 \%$ and $-0.38 \%$ and $\delta^{13} \mathrm{C}$ values between $-0.25 \%$ and $+1.45 \%$. Calcite cement (CFCalV) filling veins in the footwall damage zone of the Monte Camicia Thrust has $\delta^{18} \mathrm{O}$ of $-6.06 \%$ and $\delta^{13} \mathrm{C}$ of $+0.54 \%$. Calcite cements (CFCalP) rimming secondary dissolution pores in the fault core have low $\delta^{18} \mathrm{O}$ and $\delta^{13} \mathrm{C}$ values compared with the micritic shear bands, with values ranging from $8.30 \%$ to $-7.42 \%$ for oxygen and from $-3.86 \%$ to $+2.59 \%$ for carbon.

Bituminous dolostones host rocks (BDHR) have $\delta^{18} \mathrm{O}$ values from $-0.09 \%$ to $+2.20 \%$ and $\delta^{13} \mathrm{C}$ in the range $+1.40 \%$ o to $+2.31 \%$ o. Only four samples were collected at site CF3, and show $\delta^{18} \mathrm{O}$ values between $-2.22 \%$ and $-1.05 \%$. Dolomite faultveins in Bituminous dolostones (BDDolFV) in the haging wall of the Vado di Ferruccio Thrust have $\delta^{18} \mathrm{O}$ and $\delta^{13} \mathrm{C}$ values between $-0.48 \%$ and $+0.83 \%$, and between $+1.69 \%$ and $+2.22 \%$, respectively. A fault-vein included in bitumen layers shows depleted values with a $\delta^{18} \mathrm{O}$ value of $-2.65 \%$ and a $\delta^{13} \mathrm{C}$ value of $-1.60 \%$. Calcite micro-veins in Bituminous dolostones (BDCaIV) show depleted values of $\delta^{18} \mathrm{O}$ and $\delta^{13} \mathrm{C}$ compared to the host and have values ranging from $-6.86 \%$ to $2.93 \%$ and from $-4.68 \%$ to $+2.02 \%$, respectively. Dolostone host rocks sampled at 
site PF1 display higher $\delta^{18} \mathrm{O}$ values, comprised between $+3.26 \%$ and $+3.79 \%$, and the associated fault-veins show higher $\delta^{13} \mathrm{C}$ values, from $+2.24 \%$ o to $+2.58 \%$, compared to the bulk of the samples.

In the fault core of the Vado di Ferruccio Thrust, similar to the Monte Camicia Thrust, data were collected from a limestone-dolostone mixed material (VFCore). Isotopic values are between $-0.48 \%$ o and $+0.39 \%$ for $\delta^{18} \mathrm{O}$, and from $+1.55 \%$ o to $+2.13 \%$ for $\delta^{13} \mathrm{C}$. Vein sets VFCal1 and VFCal2, in the footwall damage zone, have depleted $\delta^{18} \mathrm{O}$ values, ranging between $-5.82 \%$ and $+0.13 \%$. Their $\delta^{13} \mathrm{C}$ values range from $-1.01 \%$ o to $+1.61 \%$. The marly limestones of the Corniola in the footwall of the thrust, show $\delta^{18} \mathrm{O}$ values between $-1.15 \%$ and $0.00 \%$, and $\delta^{13} \mathrm{C}$ values between $+1.62 \%$ and $+2.65 \%$. Only at site VF1, two lower $\delta^{13} \mathrm{C}$ values of $+0.52 \%$ o and $+0.56 \%$ were obtained. Veins CoCalV typically have $\delta^{13} \mathrm{C}$ values ranging from $+1.98 \%$ to $+2.55 \%$ and only at site VF1 they decrease to a range varying between $+0.25 \%$ and $+0.36 \%$. CoCalV show $\delta^{18} \mathrm{O}$ values between $-1.43 \%$ and $+0.22 \%$.

\subsection{Strontium isotopes data}

Strontium isotope analyses results are reported in Table S1. Eight samples were selected for strontium isotopes analysis, including two dolostone host rocks (BDHR), two dolomite fault-veins (BDDolFV), two limestone host rocks (RCHR and CoHR), a calcite vein (CoCalV), and a dolomite-calcite micritic matrix in the fault core of the Monte Camicia Thrust (CFCalDolSB). Results are shown in Fig. 18A, where host rock strontium isotope ratios are plotted vs. their depositional age (McArthur et al., 2012). Bituminous dolostones display ${ }^{87 / 86} \mathrm{Sr}$ values of 0.7079 and 0.7078 , and show a good correlation with the seawater strontium ratio of their depositional ages. A similar feature occurs also for the Corniola sample, with an ${ }^{87 / 86} \mathrm{Sr}$ value of 0.7071 , whereas Rudist calcarenites show an ${ }^{87 / 86} \mathrm{Sr}$ value of 0.7070 , which is depleted compared to the age of this formation. Plotting ${ }^{87 / 86} \mathrm{Sr}$ values versus the corresponding $\delta^{18} \mathrm{O}$ values indicates that thrusting-related dolomite fault-veins have ${ }^{87 / 86} \mathrm{Sr}$ values of 0.7077 and 0.7075 , which are depleted compared to their host rocks (Fig. 18B). The ${ }^{87 / 86} \mathrm{Sr}$ value of the calcite vein CoCalV from Corniola is 0.7073 , i.e. enriched compared to the host rock. The ${ }^{87 / 86} \mathrm{Sr}$ value from the fault core of the Monte Camicia Thrust is 0.7077 . 


\subsection{Noble gas isotope data}

Noble gas isotopic data are given in Table 2. Due to the low ${ }^{3} \mathrm{He}$ contents, it was not possible to determine the ${ }^{3} \mathrm{He} /{ }^{4} \mathrm{He}$ of any samples, however based on the minimum detection limit of ${ }^{3} \mathrm{He}$, the ${ }^{3} \mathrm{He} /{ }^{4} \mathrm{He}$ value are constrained to be $<1 \mathrm{Ra}$ (where $\mathrm{Ra}$ is the atmospheric ${ }^{3} \mathrm{He} /{ }^{4} \mathrm{He}=1.399 \times 10^{-6}$ ). Thus, it is not possible to conclusively exclude a minor component of mantle derived ${ }^{3} \mathrm{He}$, which typically has ${ }^{3} \mathrm{He} /{ }^{4} \mathrm{He}>0.1 \mathrm{Ra}$. However, ${ }^{40} \mathrm{Ar} /{ }^{36} \mathrm{Ar}$ ratios between $296-310$ indicate that atmospheric $\mathrm{Ar}$ is dominant $\left({ }^{40} \mathrm{Ar} /{ }^{36} \mathrm{Ar}\right.$ of air is 296) with a minor addition of radiogenic ${ }^{40} \mathrm{Ar}$. The presence of radiogenic ${ }^{4} \mathrm{He}$ is evident from the elevated ${ }^{4} \mathrm{He} /{ }^{36} \mathrm{Ar}$ values that are between $4-700$ times higher the air value $\left({ }^{3} \mathrm{He} /{ }^{4} \mathrm{He}=0.167\right)$, and up to 3500 times the air-saturated water value (ASW; ${ }^{4} \mathrm{He} /{ }^{36} \mathrm{Ar}=0.032$ ). Crushing is considered to release noble gases primarily from fluid inclusions, therefore, assuming that the fluids contain ASW levels of ${ }^{36} \mathrm{Ar}\left(1.5 \times 10^{-6} \mathrm{~cm}^{3} \mathrm{~cm}^{-3}\right.$ $\mathrm{H}_{2} \mathrm{O}$ ), then the measured ${ }^{4} \mathrm{He} /{ }^{36} \mathrm{Ar}$ ratios can be used to estimate fluid ${ }^{4} \mathrm{He}$ concentrations, which are in the range (0.1-1.5) $\times 10^{-4} \mathrm{~cm}^{3} \mathrm{~cm}^{-3} \mathrm{H}_{2} \mathrm{O}$ (Table 2). These ${ }^{4} \mathrm{He}$ concentrations are up to 700 times higher than expected for ASW $(1 \times 10$ ${ }^{8} \mathrm{~cm}^{3} \mathrm{~cm}^{-3} \mathrm{H}_{2} \mathrm{O}$ ) and help to confirm the presence of an 'excess' ${ }^{4} \mathrm{He}$ component. ${ }^{4} \mathrm{He}$ accumulation in aquifers results from the radioactive decay of $U$ and $T h$ in the host rocks, followed by diffusion into the fluid-filled pore space. The high diffusivity of ${ }^{4} \mathrm{He}$ in minerals means that it is continuously lost from crustal minerals at a rate approximately equal to that of its production (Torgersen and Clarke, 1985; Torgersen, 1989). Thus, ${ }^{4} \mathrm{He}$ accumulation can be used to estimate the water residence time in the aquifer system, and depends upon the ${ }^{4} \mathrm{He}$ content of the fluid, the ${ }^{4} \mathrm{He}$ production rate and the host rock porosity. The upper crustal production rate is estimated to be $\sim 0.6 \times 10^{-12} \mathrm{~cm}^{3}{ }^{4} \mathrm{He} \mathrm{g} \mathrm{yr}{ }^{-1}$ (Ballentine and Burnard, 2002) and does not normally vary by more than a factor of two irrespective of host rock lithology. The porosity of the host limestones and dolostones has been determined on 40 samples to be in the range $0.1-9.7 \%$ with a mode at $2.8 \%$, and $38 / 40$ samples have porosity $<6 \%$ (Cilona et al., 2019). Using the maximum ${ }^{4} \mathrm{He}$ fluid concentration estimated earlier of $1.5 \times 10^{-4} \mathrm{~cm}^{3} \mathrm{~cm}^{-3} \mathrm{H}_{2} \mathrm{O}$, yields a residence age of $\sim 7 \mathrm{Ma}$ assuming a porosity $2.8 \%$, increasing to $\sim 14 \mathrm{Ma}$ for a porosity of $6 \%$. The above estimate neglects any uncertainties related to any additional flux of ${ }^{4} \mathrm{He}$ that may derive from beneath the aquifer, and therefore should be considered an upper limit 
(Torgersen and Clarke, 1985; Torgersen and Ivey, 1985; Pinti and Marty, 1995). The different uncertainties associated to this rather simplistic calculation, means that fluid residence age are conservatively estimated to at the Ma-timescale.

The heavy noble gas data are shown on a plot of ${ }^{84} \mathrm{Kr} /{ }^{36} \mathrm{Ar}$ vs ${ }^{132} \mathrm{Xe} /{ }^{36} \mathrm{Ar}$ in Fig 19. The data form a correlation between air and ASW endmembers. A few samples, notably the Bituminous dolostone host rock, have elevated ${ }^{132} \mathrm{Xe} /{ }^{36} \mathrm{Ar}$ values which can be accounted for by preferential Xe absorption on organic material. The massive dolostone samples tend to have more air-like ${ }^{84} \mathrm{Kr} /{ }^{36} \mathrm{Ar}$ values $<0.0282$, whereas limestone and calcite cement samples have ${ }^{84} \mathrm{Kr} /{ }^{36} \mathrm{Ar}$ values always $>0.0279$, closer to the ASW end-member. The presence of air noble gases indicates that the samples may be contaminated with modern atmosphere added during sample preparation, this would also account for ${ }^{40} \mathrm{Ar} /{ }^{36} \mathrm{Ar}$ values closest to the air value of 296. However, it is also possible that there may be a component of paleoatmosphere that was entrained as partially dissolved gas during meteoric recharge of the aquifer fluids.

\section{Discussion}

\section{1 Host rocks diagenetic framework}

Corniola in the tectonic window of the Vado di Ferruccio Thrust show $\delta^{18} \mathrm{O}$ and strontium isotope ratios values in the range of Lower Jurassic seawater and $\delta^{13} \mathrm{C}$ values distributed in two clusters, slightly higher and lower than seawater values, respectively (Figs. 17A-B-C, 18A). This could indicate that bacterially-mediated processes occurred during early-diagenesis in the marly sediments of the Corniola (Hoefs, 1997).

Bituminous dolostones in TS2 have $\delta^{18} \mathrm{O}$ values enriched by $+2 \%$ to $+3.5 \%$ compared to the Upper Triassic seawater value (Fig. 17B). $\delta^{18} \mathrm{O}$ fractionation of $+3 \%$ to $+4 \%$ in dolomite compared to calcite at low temperature (Land, 1980), supports the hypothesis that seawater was likely the main fluid involved in early-diagenetic dolomite precipitation, although recrystallization during burial can't be excluded based on stable isotope data alone (Machel, 2004). Samples from site PF1 (see Fig. 9), characterized by heavier $\delta^{18} \mathrm{O}$ values, can be explained by interaction with slightly evaporated seawater during early-diagenesis. These inferences agree with $\delta^{13} \mathrm{C}$ 
values and the strontium isotope ratios (Figs. 17C, 18A). The high ${ }^{132} \mathrm{Xe} /{ }^{36} \mathrm{Ar}$ ratio of the Bituminous dolostone is likely due to preferential adsorption of ${ }^{132} \mathrm{Xe}$ by organic matter (Fig. 19, Hohenberg et al., 2002). The negative shift of $\delta^{18} \mathrm{O}$ values from samples collected in Site CF3 is caused by contamination of meteoric calcite, which occurs as micritic cement in these samples.

Rudist calcarenites in the hanging wall of the Monte Camicia Thrust show $\delta^{18} \mathrm{O}$ and $\delta^{13} \mathrm{C}$ values that correspond to the mean ranges of the Lower Cretaceous seawater stable isotopic composition (Fig. 17B-C). However, their strontium isotopes ratio does not fit with this age (Fig. 18A). This feature could be explained taking into account that the Rudist calcarenites are partly made of carbonate detrital material derived from older carbonate rocks of the Adria passive margin succession, thus lowering the strontium isotope ratio or due to erroneous stratigraphic correlations in the study area.

\subsection{Structural diagenesis}

The older vein set exposed in the studied thrust sheet pile, labelled CoCalV, is cut by all the studied deformation structures and, consequently, it predates out-ofsequence thrusting and is likely related to early thrusting and folding. CoCalV veins are characterized by mean $\delta^{18} \mathrm{O}$ and $\delta^{13} \mathrm{C}$ values comparable to those of the Corniola host rock (Figs. 17A-B-C, 18A) and their strontium isotope ratio is slightly higher than the host rock value (Fig. 18B). These features support crystallization from formational fluids in closed system conditions, at low water/rock ratios (Dietrich \& McKenzie, 1983).

The mutual cross-cutting relationships between VFCal1 veins and tectonic stylolites in the footwall damage zone of the Vado di Ferruccio Thrust (Fig. 20A), indicate that the former precipitated coevally with pressure solution (e.g. Ramsay, 1980; Ghisetti, 1987). Their cathodoluminescence colours, darker than the host rock, $\delta^{13} \mathrm{C}$ values similar to both hanging wall and footwall host rocks, and $\delta^{18} \mathrm{O}$ values from $0 \%$ to $-3 \%$, suggest either (i) heterogeneous fluid compositions resulting from different degrees of mixing between fluids circulating in equilibrium with the footwall and hanging wall damage zones, or (ii) precipitation from the same fluid at different temperatures (Friedman \& O'Neil, 1977; Muchez et al., 1995). From the structural point of view, we consider the first hypothesis as the more reliable one. 
Different cathodoluminescence colours of idiotopic-E-dolomite crystals in the fault core of the Vado di Ferruccio Thrust, compared to the host dolostones and the fault-veins, suggest that they grew from dolomitizing fluids characterized by a different chemical signature with respect to those in the hanging wall damage zone. Stylolites have been documented to be characterized by different chemical properties with respect to the surrounding limestones, and may have promoted localized dolomitization (Warren, 2000; Evans \& Elmore, 2006). However, the Vado di Ferruccio Thrust west of Mt. Brancastello (Fig. 2B) is characterized by widespread dolomitization of the fault zone, overprinting major fault activity (Demurtas et al., 2016). This may suggest that idiotopic-E-dolomite crystals formed during the same metasomatic event in the fault core of the Vado di Ferruccio Thrust. Fluids circulating in the fault core also contained dissolved silica that precipitated in microcrystalline bands within the hanging wall damage zone by re-opening tectonic stylolites and dolomite fault-veins (Fig. 20A). Considering that strontium isotopes do not record high ${ }^{87} \mathrm{Sr} /{ }^{86} \mathrm{Sr}$ ratios in dolomite fault-veins, a typical feature of fluids that interacted with siliciclastic rocks, silica may have been sourced by local dissolution of chert nodules present in carbonate rocks.

The abundance of thrust-parallel and low-angle crackle fault-veins (BDDolFV) affecting Bituminous dolostones indicates that they formed at pore fluid overpressure conditions, possibly with fluid pressures higher than lithostatic (Sibson, 1981, 1990). Dolomite crystals in the veins display $\delta^{18} \mathrm{O}$ and $\delta^{13} \mathrm{C}$ values in the same range of the Bituminous dolostones host rock (Fig. 17). Strontium isotopes ratios are slightly depleted compared to that of the host rocks, but still in the range of the analyzed Mesozoic carbonatic rocks (Fig. 18B). All this evidence and the same cathodoluminescence colours between dolomite fault-veins and dolostones, imply that the former crystallized during thrusting from fluids with isotopic and chemical compositions similar to their host rocks. This could be the result of fluid circulation in closed system conditions, or at low water/rock ratios during fluid-rock interaction, by fluids with marine affinity (Fig. 20A; Ghisetti et al., 2001; Kirschner \& Kennedey, 2001).

Cataclastic shear bands in Bituminous dolostones (CFCalDolSB) involved in the footwall damage zone of the Monte Camicia Thrust have $\delta^{18} \mathrm{O}$ and $\delta^{13} \mathrm{C}$ values that are intermediate between the isotopic composition of the host rock and that of 
the micritic calcite shear bands in the fault core (Figs. 17A-B-C). Shear bands (CFCalSB) and micro-veins (CFCalV) have cathodoluminescence colours indicating oxic to suboxic conditions and $\delta^{18} \mathrm{O}$ and $\delta^{13} \mathrm{C}$ values typical of meteoric fluids which interacted at different degrees with the carbonate hosts suggesting cementation in a phreatic-meteoric environment (Figs. 17A-B-C; Fig. 20B; e.g. Ghisetti et al., 2001; Agosta \& Kirschner, 2003; Agosta et al., 2008; Smeraglia et al., 2016).

Summarizing, petrographic and geochemical evidence from veins and shear bands associated with contractional deformations, indicate that fluids involved in outof-sequence thrusting along the Vado di Ferruccio Thrust are characterized by marine and/or connate fluids signature and semi-closed system conditions. Their migration pathways were likely restricted to the carbonate Mesozoic succession (Fig. 20B) while those that circulated during out-of-sequence thrusting at shallow depth in the Monte Camicia thrust fault zone are of meteoric origin and infiltrated from the surface (Fig. 20A). Noble gas geochemistry indicates that volatiles dissolved in fluids are a mixture of atmosphere and air-saturated water-derived, with addition of ${ }^{4} \mathrm{He}$ acquired during fluid circulation. Thus, the influence of significant external fluid sources like the basement (radiogenic noble gases ${ }^{4} \mathrm{He}$ and ${ }^{40} \mathrm{Ar}$ ) and the mantle $\left({ }^{3} \mathrm{He}\right)$ can be excluded (Ballentine \& Burnard, 2002; Ballentine et al., 2002).

In the Vado di Ferruccio Thrust (VFCal2), cathodoluminescence orange colours and moderately depleted oxygen and carbon stable isotope values of calcite cements from deformation features produced by extensional faulting are interpreted as being precipitated from meteoric fluids with different degrees of water-rock interaction in a deep phreatic-meteoric or shallow burial environment (less than $\sim 1.5$ km depth; Fig. 20D). Furthermore, in extension-related cements associated with the extensional reactivation of the Monte Camicia Thrust (CFCalP), depleted oxygen and carbon isotope values indicate that calcite precipitated from infiltrating meteoric fluids in the vadose zone; this is also confirmed by their association with specific textures characteristic of this diagenetic environment (Fig. 20C; Allan \& Matthews, 1982; Agosta \& Kirschner, 2003; Hausegger et al., 2010; Cooley et al., 2011). Calcite precipitation from meteoric fluids following different degrees of water-rock interaction, can be inferred also from geochemical and petrographic features of cements associated with the master extensional fault zones (BDCalV) that dissect both the Monte Camicia and Vado di Ferruccio thrusts to the south, and bound the Campo 
Imperatore basin in this area. These cements are non-luminescent, indicating oxic fluids, and show depleted $\delta^{18} \mathrm{O}$ and $\delta^{13} \mathrm{C}$. Similar environmental conditions during extensional faulting have been proposed by other authors in the Gran Sasso region and in the Central Apennines in general (Ghisetti et al., 2001; Ronchi et al., 2004; Bussolotto et al., 2007; Agosta et al., 2008; Dewever et al., 2010; Smeraglia et al., 2016). Noble gas geochemistry allows us to exclude any significant fluid contribution from the basement and the mantle to the fault zone paleofluid circulation (Table 2).

9.3 Extensional reactivation of the Monte Camicia Thrust: reconciling a long lasting kinematic debate

Our new structural data collected along the Monte Camicia Thrust (Fig. 4), support contractional kinematics, as initially proposed by Ghisetti and Vezzani (1986), rather than the extensional one suggested by D'Agostino et al. (1998) and Pace et al. (2014). However, extensional re-activation of the master slip surface and subsidiary extensional faults soling into it occur as well, particularly along the southern sector, well exposed in the Miniera di Lignite area (Fig. 9). Accordingly, our structural data help to reconcile the two previously proposed alternative interpretations by supporting dominant out-of-sequence thrusting, followed by subordinate negative inversion.

Our preferred tectonic interpretation for the onset of extensional reactivation is footwall collapse associated with development of the Campo Imperatore extensional fault system. This implies a Quaternary age of faulting for the extensional failure of the Monte Camicia Thrust (D'Agostino et al., 1998). In particular, we propose that activity of the Campo Imperatore Fault caused progressive decrease of tectonic confinement on the Monte Camicia Thrust, and consequent release of fault strength. Eventually, the southern segment of the Monte Camicia thrust ramp failed in extension due to gravity, the Miniera di Lignite fault zone formed in the hanging wall and favoured dilation of the contractional structural fabric to the south, and its evolution into a protobreccia (Fig. 21).

9.4 Evolution of faulting in the Gran Sasso thrust stack

Newly acquired multidisciplinary datasets allow us to place the multiple fault activity recorded by the Vado di Ferruccio Thrust and Monte Camicia Thrust in the 
Gran Sasso Massif into the framework of Neogene-Quaternary dynamic evolution of the Central Apennines thrust wedge which propagated into a complex paleogeography of fault-bounded carbonate platform blocks at the transition to the Umbria-Marche basinal domain (Fig. 22A; e.g. Centamore et al., 1975; Cosentino \& Parotto, 1986; Santantonio, 1993; Cardello \& Doglioni, 2015). Before describing our evolutionary model, it has to be emphasized that, at a regional scale, the Vado di Ferruccio and Monte Camicia out-of-sequence thrusts developed after folding of the Adria passive margin succession (Fig. 22B) and that most likely belong to the same thrust system (cf. Ghisetti et al., 1991; 1993a), with the latter being a splay of the former (Figs. 2B and 22C). We refer to this contractional deformation structure as the Campo Imperatore thrust system (Fig. 22C), that itself, may splay off the Gran Sasso Thrust.

Development of the Gran Sasso Frontal Thrust and associated folding started in Messinian times in a piggyback fashion (Ghisetti \& Vezzani, 1986, 1991; Cipollari \& Cosentino, 1995; Centamore \& Rossi, 2009), carrying the Gran Sasso carbonate thrust sheet onto the Messinian Laga foredeep deposits (Figs. 22C). In order to maintain the thrust wedge at the mechanical equilibrium between tectonic and gravitational forces, and to account for the effects of surface processes in the hinterland (Davis et al., 1983; Konstantinovskaya \& Malavieille, 2005, 2011), underthrusting occurred beneath the Gran Sasso Frontal Thrust, and out-ofsequence thrusting affected the folded Mesozoic succession in the Gran Sasso thrust sheet, possibly triggered by abundant syntectonic sedimentation at the wedge toe (e.g. Storti \& McClay, 1995; Bigi et al., 2011; Marini et al., 2015). The Vado di Ferruccio Thrust formed at this stage, cutting through the Gran Sasso anticline and associated thrust, which overthrusted the Messinian-Lower Pliocene Laga siliciclastics (Ghisetti \& Vezzani 1986; Fig. 22D). Deformation still occurred in a wedge top marine environment, as indicated by structural diagenesis evidence.

During middle Pliocene times, with in-sequence thrusting shifting further northeastwards, erosion started in the Gran Sasso Massif area (Centamore \& Nisio, 2003; Centamore \& Rossi, 2009). The concomitant effect of forelandward propagation of the wedge toe and erosional thinning in the emerged region hinterlandward, caused shallowing of the surface taper angle and this, in turn, eventually triggered further out-of-sequence thrusting to restore the mechanical equilibrium of the wedge (Davis et al., 1983; Cruz et al., 2010; Graveleau et al., 
2012). The effects of renewed tectonic activity in the Gran Sasso thrust stack were likely underthrusting at depth and re-activation of the Campo Imperatore thrust system, which produced the Monte Camicia splay thrust at near surface conditions in a subaerial environment, as shown by structural diagenesis evidence. Its youngeron-older stratigraphic separation indicates that it transported rocks from the backlimb onto the forelimb of the previously formed Gran Sasso anticline (Fig. 22E).

Extensional tectonics affected the Gran Sasso thrust stack in Quaternary times (e.g. Ghisetti \& Vezzani, 1999; Cosentino et al., 2010), producing some extensional reactivation in the contractional structural architecture in the footwall of the SSW-dipping Campo Imperatore extensional fault system (e.g. Demurtas et al., 2016; Leah et al., 2018), and creating accommodation space for fluvio-glacial continental sediments in the hanging wall (e.g. Giraudi \& Frezzotti, 1997; Fig. 22F). Deciphering whether the switch from contraction to extension was triggered by the northeastward migration of "Tyrrhenian lithosphere thinning" (e.g. Elter et al., 1975), or by gravitational re-equilibration of a supercritical Pleistocene Central Apennines thrust wedge is a matter for further research. Our geochemical dataset and the recently proposed causal link between thrust stacking at depth and extensional faulting in the uplifting thrust sheets of the Montagna dei Fiori antiformal stack (Storti et al., 2018), at the footwall of the Gran Sasso Frontal Thrust, may support a similar tectonic evolution.

\section{Conclusions}

Our multidisciplinary study including structural, petrographical, microthermometric, and geochemical analyses, allows us to shed new light onto the still debated tectonic evolution of the Gran Sasso thrust stack, in the Central Apennines.

The S-dipping, N-verging Monte Camicia Thrust, at the top of the Gran Sasso thrust stack, has a dominant contractional kinematics despite showing a younger-on-older stratigraphic separation. The thrust converges downdip towards the underlying Vado di Ferruccio Thrust and this strongly supports the hypothesis that, at regional scale, both faults belong to the same out-ofsequence thrust system, which we refer to as the Campo Imperatore thrust system. 
- Structural diagenesis data indicates that fluid-rock interaction during the late Messinian-early Pliocene out-of-sequence activity of the Vado di Ferruccio Thrust was characterized by semi-closed system conditions and by the involvement of fluids with marine signature, as indicated by isotopic data. This suggests that thrust activity occurred in a wedge top basin environment. In contrast, middle Pliocene out-of-sequence activity of the Monte Camicia Thrust was characterized by meteoric fluid infiltration from the surface along the fault zone, which equilibrated at different degrees with the carbonate hosts, and caused calcite precipitation in a surficial phreatic meteoric environment. This supports the subaerial activity of the thrust, which resulted in dolomite dissolution and calcitization processes along the fault zone.

- Combining stratigraphic, geometric, structural, and diagenetic constraints indicate multiple out-of-sequence activity of the Campo Imperatore thrust system, which affected the Gran Sasso anticline, first by dissecting the forelimb in submarine environmental conditions (Vado di Ferruccio Thrust), and then eventually by folding. Renewed thrusting caused translation of the backlimb onto the forelimb, in subaerial environmental conditions (Monte Camicia Thrust).

The geodynamic reason for such a multiple out-of-sequence thrust activity in the Gran Sasso thrust stack, is based on the mechanical balance between gravitational and tectonic forces in the Messinian-Quaternary Central Apennine thrust wedge. Piggyback thrust nucleation at the wedge toe, syntectonic sedimentation in the wedge top basin of the Adriatic foreland basin system, and syntectonic erosion in the subaerial rear of the wedge, determined the progressive shallowing of the surface taper and, consequently, the subcritical stage of the thrust wedge. To recover the mechanical equilibrium, i.e. the critical stage, a combination of underthrusting at depth and out-of-sequence thrusting was triggered. Structural and diagenetic data from the Campo Imperatore thrust system indicate that multiple cycles of subcritical to critical conditions occurred in the MessinianPliocenic Central Apennines thrust wedge, causing out-of-sequence thrusting pulses involving the Gran Sasso thrust stack, which was subsequently affected by contractional deformation after undergoing erosion, exhumation, 
and subaerial exposure. This idea could help account for the preservation of the spectacular topographic relief of the Gran Sasso Massif.

- Gravity-induced re-equilibration within the growing Gran Sasso thrust stack may provide a "local mechanical reason" for the onset of Quaternary extensional deformations overprinting the contractional structural architecture, rather than outward propagation of the Tyrrhenian back-arc shoulder. Development of the Campo Imperatore extensional fault system caused formation of subsidiary extensional fault zones in the footwall, exploiting thrust segments as detachment levels. As a result of such extensional reactivation, the southern sector of the Monte Camicia thrust hanging wall damage zone underwent dilation and was mostly transformed into a proto-breccia.

- Noble gas geochemistry of vein cements rules out any significant contribution of deeply sourced fluids during both contractional and extensional faulting. The results, therefore, suggest that the structural architecture exposed at the surface is not directly linked with the seismogenic fault pattern at depth. However, the thrust network at shallow depth provides mechanical discontinuities suitable to undergo extensional reactivation during extensional coseismic faulting, thus constituting a bias factor for earthquake scaling laws.

\section{Acknowledgements}

We are indebted to Andrea Comelli for thin section preparation, Enrico Selmo for providing carbon and oxygen stable isotope data, Zita Kelemen for support with the micromilling equipment, and Paolo Gentile for help with SEM microscopy. Strontium isotope data were provided by Gareth Davies, at Vrije Universiteit, Amsterdam. Fieldwork was partly funded by Shell Global Solutions International B.V., Amsterdam, The Netherlands. The "Ente Parco Nazionale del Gran Sasso e Monti della Laga" is thanked for permission to conduct fieldwork in the Campo Imperatore area. Author's contributions: Alessio Lucca participated in some fieldwork, performed the microstructural, diagenetic and isotopic work, and wrote the manuscript; Fabrizio Storti conceived the research and, together with Fabrizio Balsamo, acquired most of the structural data and participated in the tectonic interpretation; Luca Clemenzi, Michele Fondriest and Giulio Di Toro participated in some fieldwork and contributed to the discussion of tectonic interpretations; Ray Burgess participated in the analyses and interpretation of noble gases isotope data 
in syntectonic cements. All co-authors critically revised the manuscript. Full geochemical analyses results are available in the earthchem.org/library data repository, DOI: 10.1594/IEDA/111425.

\section{References}

Accordi, G., \& Carbone, F. (1986). Lithofacies map of Latium-Abruzzi and neighbouring areas, scale 1:250.000, Progetto Finalizzato Geodinamica, Consiglio Nazionale Ricerche Italy, Roma.

Adamoli, L., Bigozzi, A., Ciarapica, G., Cirilli, S., Passeri, L., Romano, A., Duranti, F., \& Venturi, F. (1990). Upper Triassic bituminous facies and hettangian pelagic facies in the Gran Sasso range: Boll. Soc. Geol. It., 109, 219-230.

Agosta, F., \& Kirschner, D.L. (2003). Fluid conduits in carbonate-hosted seismogenic normal faults of Central Italy: Journal of Geophysical Research, 108 (B4), 2221, doi:10.1029/2002JB002013.

Agosta, F., Mulch, A., Chamberlain, P., \& Aydin, A. (2008). Geochemical traces of CO2-rich fluid flow along normal faults in central Italy: Geophys. J. Int., 174, 758-770.

Allan, J.R., \& Matthews, R.K. (1977). Carbon and oxygen isotopes as diagenetic and stratigraphic tools: surface and subsurface data, Barbados, West Indies: Geology, 5, 16-20.

Allan, J.R., \& Matthews, R.K. (1982). Isotopic signatures associated with early meteoric diagenesis: Sedimentology, 29, 797-817.

Alvarez, W., Engelder, T., \& Lowrie, W. (1976). Formation of spaced cleavage and folds in brittle limestone by dissolution: Geology, 4, 698-701.

Ascione, A., Cinque, A., Miccadei, E., \& Villani, F. (2008). The Plio-Quaternary uplift of the Apennines Chain: new data from the analysis of topography and river valleys in Central Italy: Geomorphology, 102, 105-118. doi:10.1016/j.geomorph.2007.07.022.

Ballentine, C.I., Burgess, R., \& Marty, B. (2002). Tracing fluid origin, transport and interaction in the crust: Rev. Mineral. Geochem., 47, 539-614.

Ballentine, C.J., \& Burnard, P.G. (2002). Production, release and transport of noble gases in the continental crust: Rev. Mineral. Geochem., 47, 481-538. 
Bally, A.W., Burbi, L., Cooper, C., \& Ghelardoni, R. (1986). Balanced sections and seismic reflection profiles across the central Apennines: Memorie della Società Geologica Italiana, 35, 257-310.

Balsamo, F., Clemenzi, L., Storti, F., Mozafari, M., Solum, J., Swennen, R., Taberner, C., \& Tueckmantel, C. (2016). Anatomy and paleofluid evolution of laterally-restricted extensional fault zones in the Jabal Qusaybah anticline, Salakh Arc, Oman: Geological Society of America Bulletin, 128, 957-972, doi: 10.1130/B31317.1.

Banner, J.L., \& Hanson, G.N. (1990). Calculation of simultaneous isotopic and trace element variations during water-rock interaction with applications to carbonate diagenesis: Geochimica et Cosmochimica Acta, 54, 3123-3137.

Banner, J.L. (1995). Applications of the trace element and isotope geochemisty of strontium to studies of carbonate diagenesis: Sedimentology, 45 (2), 805-824.

Barchi, M., Minelli, G. \& Pialli, G. (1998). The CROP03 profile: a synthesis of result on deep structures of the Northern Apennines: Mem. Soc. geol. It., 52, 383400.

Barker, C.E., \& Halley, R.B. (1988). Fluid inclusions in vadose cement with consistent vapor to liquid ratios, Pleistocene Miami Limestone, southeastern Florida: Geochimica et Cosmochimica Acta, 52, 1019-1025.

Bartolini, C., D’Agostino, N., \& Dramis, F. (2003). Topography, exhumation, and drainage network evolution of the Apennines: Episodes, 23, 212-217.

Bigi, S., Casero, P. \& Ciotoli, G. (2011). Seismic interpretation of the Laga basin; constraints on the structural setting and kinematics of the Central Apennines: Journal of the Geological Society, 168(1), 179-190.

Billi, A., Tiberti, M.M., Cavinato, G.P., Cosentino, D., Di Luzio, E., Keller, J.V.A., Kluth, C., Orlando, L., Parotto, M., Praturlon, A., Romanelli, M., Storti, F., \& Wardell, N. (2006). First results from the CROP-11 deep seismic profile, central Apennines, Italy: evidence of mid-crustal folding: Journal of the Geological Society, London, 163, 583-586.

Boyer, S.E. (1992). Geometric evidence for synchronous thrusting in the southern Alberta and northwest Montana thrust belts. In: K.R. McClay (ed.), Thrust Tectonics, Chapman and Hall, New York, 377-390.

Breesch, L., Swennen, R., \& Vincent, B. (2009). Fluid flow reconstruction in hanging and footwall carbonates: compartmentalization by Cenozoic reverse faulting in 
the Northern Oman Mountains (UAE). Mar. Pet. Geol., 26, 113-128. http://dx.doi.org/10.1016/j.marpetgeo.2007.10.004.

Burke, W.H., Denison, R.E., Hetherington, E.A., Koepnick, R.B., Nelson, H.F., \& Otto, J.B. (1982). Variation of seawater ${ }^{87} \mathrm{Sr} /{ }^{86} \mathrm{Sr}$ throughout Phanerozoic time: Geology, 10, 516-519.

Burkhard, M. (1993). Calcite twins, their geometry, appearance and significance as stress- strain markers and indicators of tectonic regime: a review. Journal of Structural Geology, 15, 351-368.

Burkhard, M., Kerrich, R. (1988). Fluid regimes in the deformation of the Helvetic nappes, Switzerland, as inferred from stable isotope data: Contrib. Mineral. Petrol., 99, 416-429.

Bussolotto, M., Benedicto, A., Invernizzi, C., Micarelli, L., Plagnes, V., \& Deiana, G. (2007). Deformation features within an active normal fault zone in carbonate rocks: the Gubbio fault (Central Apennines, Italy): Journal of Structural Geology, 29, 2017-2037.

Butler, R.W.H. (1987). Thrust sequences: Journal of the Geological Society of London, 144, 619-634.

Calamita, F., \& Deiana, G. (1988). The arcuate shape of the Umbria-Marche-Sabina Apennines (Central Italy): Tectonophysics, 146, 139-147.

Calamita, F., Paltrinieri, W., Pelorosso, M., Scisciani, V., \& Tavarnelli, E. (2003). Inherited Mesozoic architecture of the Adria continental paleomargin in the Neogene central Apennines orogenic system, Italy: Boll. Soc. Geol. Ital., 122, 307-318.

Cardello, G.L., \& Doglioni, C. (2014). From Mesozoic rifting to Apennine orogeny: The Gran Sasso range (Italy): Gondwana Research,http://dx.doi.org/10.1016/j.gr.2014.09.009.

Carminati, E., Corda, L., Mariotti, G., Scifoni, A., \& Trippetta, F. (2013). Mesozoic syn- and postrifting evolution of the Central Apennines, Italy: the role of Triassic evaporites: Journal of Geology, 121, 327-354.

Carminati, E., Fabbi, S., \& Santantonio, M. (2014). Slab bending, syn-subduction normal faulting, and out-of-sequence thrusting in the Central Apennines: Tectonics, 33, 530-551. 
Castellarin, A., Colacicchi, R., \& Praturlon, A. (1978). Fasi distensive, trascorrenze e sovrascorrimenti lungo la "Linea Ancona-Anzio," dal Lias medio al Pliocene: Geologica Romana, 17, 161-189.

Cavinato, G.P., Cosentino, D., De Rita, D., Funiciello, R., \& Parotto, M. (1994). Tectonic-sedimentary evolution of intrapenninic basins and correlation with the volcano-tectonic activity of central Italy: Memorie Descrittive Servizio Geologico Italiano, 39, 44-59.

Cavinato, G.P., \& De Celles, P.G. (1999). Extensional basins in the tectonically bimodal central Apennines fold-thrust belt, Italy: Response to corner flow above a subducting slab in retrograde motion: Geology, 27, 955-958.

Centamore, E., Jacobacci, A., Malferrari, N., Martelli, G., Pieruccini, U., \& Valletta, M. (1975). Carta Geologica d'Italia alla scala 1:50.000, F291 Pergola: Servizio Geologico D'ttalia.

Centamore, E., \& Nisio, S. (2003). Effects of uplift and tilting in the Central-Northern Apennines, Italy: Quat. Int., 101-102, 93-101.

Centamore, E., \& Rossi, D. (2009). Neogene-Quaternary tectonics and sedimentation in the Central Apennines: Ital. J. Geosci. (Boll. Soc. Geol. It.), 128 (1), 73-88.

Chiarabba, C., \& Amato, A. (1996). Crustal velocity structure of the Apennines (Italy) from P-wave travel time tomography: Ann. Geofis., 39, 1133-1148.

Ciarapica, G. (1990). Central and Northern Apennines during the Triassic: a review: Boll. Soc. Geol. It., 109 (1), 39-50.

Ciarapica, G., \& Passeri, L. (1998). Evoluzione paleogeografica degli Appennini: Atti Ticinensi di Scienze della Terra, 40, 233-290.

Ciarapica, G. (2007). Regional and global changes around the Triassic-Jurassic boundary reflected in the late Norian-Hettangian history of the Apennine basins: Palaeogeography, Palaeoclimatology, Palaeoecology, 244, 34-51.

Cilona, A., Solum, J.G., Lucca, A., Stroti, F., Balsamo, F., \& Taberner, C. (2018). Evolution of pore types and petrophysical properties of fault rocks in lowporosity carbonates: in Carbonate pore systems: new developments and case studies, SEPM Special Publication, No. 112, doi:10.2110/sepmsp.112.10.

Cipollari, P., Cosentino, D. \& Parotto, M. (1995). Modello cinematico-strutturale dell'Italia centrale: Studi Geologici Camerti, Vol. Spec. 1995/2, 135-143. 
Cipollari, P., Cosentino, D., Esu, D., Girotti, O., Gliozzi, E., \& Praturlon, A. (1999). Thrust-top lacustrine-lagoonal basin development in accretionary wedges: late Messinian (Lago-Mare) episode in the central Apennines (Italy): Palaeogeography, Palaeoclimatology, Palaeoecology, 151, 149-166.

Colacicchi, M., \& Praturlon, A. (1965). Stratigraphical and paleontological investigations on the Mesozoic shelf-edge facies in Eastern Marsica (Central Apennines, Italy): Geologica Romana, 4, 89-118.

Cooley, M.A., Price, R.A., Kyser, T.K., \& Dixon, J.M. (2011). Stable-isotope geochemistry of syntectonic veins in Palaeozoic carbonate rocks in the Livingstone Range anticlinorium and their significance to the thermal and fluid evolution of the southern Canadian foreland thrust and fold belt: AAPG Bull., 95, 185-1882.

Corrado, S. (1995). Optical parameters of maturity of organic matter dispersed in sediments: first results from the central Apennines (Italy): Terra Nova, 7, 338347.

Cosentino, D., \& Parotto, M. (1986). Assetto strutturale dei Monti Lucretili settentrionali (Sabina): Nuovi dati e schema tettonico preliminare: Geologica Romana, 8, 73-90.

Cosentino, D., Cipollari, P., Marsili, P., \& Scrocca, D. (2010). Geology of the Central Apennines: A regional review: in Beltrando, M., Peccerillo, A., Mattei, M., Conticelli, S., \& Doglioni, C., eds., The Geology of Italy: Journal of the Virtual Explorer (Electronic Edition), 36, paper 11.

Cosentino, D., Asti, R., Nocentini, M., Gliozzi, E., Kotsakis, T., Mattei, M., Esu, D., Spadi, M., Tallini, M., Cifelli, F., Pennacchioni, M., Cavuoto, G., \& Di Fiore, V. (2017). New insights into the onset and evolution of the central Apennine extensional intermontane basins based on the tectonically active L'Aquila Basin (central Italy): GSA Bull., 129 (9/10), 1314-1336.

Cruz, L., Malinski, J., Wilson, A., Take, W.A., \& Hilley, G. (2010). Erosional control of the kinematics and geometry of fold-and-thrust belts imaged in a physical and numerical sandbox: Journal of Geophysical Research 115, B09404, doi:10.1029/2010JB007472.

D'Agostino, N., Chamot-Rooke, N., Funiciello, R., Jolivet, L., \& Speranza, F. (1998). The role of pre-existing thrust faults and topography on the styles of extension in the Gran Sasso range (Italy): Tectonophysics, 292, 229-254. 
D'Agostino, N., Jackson, J.A., Dramis, F., \& Funiciello, R. (2001). Interactions between mantle upwelling, drainage evolution and active normal faulting: an example from the central Apennines (Italy): Geophys. J. Int., 147, 475-497.

Dahlen, F.A., Suppe, J., \& Davis, D. (1984). Mechanics of fold-and-thrust belts and accretionary wedges: Coiesive Coulomb theory: Journal of Geophysical Research, 89, 10,087-10,101.

Dahlen, F.A., (1990). Critical taper model of fold-and-thrust belts and accretionary wedges: Annual Review of Earth and Planetary Sciences, 18, 55-99.

Davis, D.M., Suppe, J., \& Dahlen, F.A. (1983). Mechanics of foldand-thrust belts and accretionary wedges: J. Geophys. Res., 88, 1153-1172.

Davis, D.M., \& Engelder, T. (1985). The role of salt in foldand-thrust Belts: Tectonophysics, 119, 67-88.

DeCelles, P.G., \& Giles, K.N., (1996). Foreland basin systems: Basin Research, 8, 105-123.

Dela Pierre, F., Ghisetti, F., Lanza, R., \& Vezzani, L. (1992). Palaeomagnetic and structural evidence of Neogene tectonic rotation of the Gran Sasso range (central Apennines, Italy): Tectonophysics, 215, 335-348.

Demurtas, M., Fondriest, M., Balsamo, F., Clemenzi, L., Storti, F., Bistacchi, A., Di Toro, G. (2016). Structure of a normal seismogenic fault zone in carbonates: The Vado di Corno Fault, Central Apennines (Italy): Journal of Structural Geology, 90, 185-206.

Dewever, B., Berwouts, I., Swennen, R.L., Breesch, L., \& Ellam, R. (2010). Fluid flow reconstruction in karstified Panormide platform limestones (north-central Sicily): Implications for hydrocarbon prospectivity in the Sicilian fold and thrust belt: Marine and Petroleum Geology, 27, (4), 939-958.

Dewey, J.F., Helman, M.L., Knott, S.D., Turco, E., \& Hutton, D.H.W. (1989). Kinematics of the western Mediterranean, In: Coward M.P., Dietrich D., and Park R.G., eds., Alpine Tectonics: Geological Society of London Special Publication, 45, 265-283.

Di Luzio, E., Mele, G., Tiberti, M.M., Cavinato, G.P., \& Parotto, M. (2009). Moho deepening and shallow upper crustal delamination beneath the central Apennines: Earth and Planetary Science Letters, 280, 1-12.

Dickson, J.A.D. (1966), Carbonate identification and genesis as revealed by staining. Journal of Sedimentary Petrology, 32, 491-505. 
Dietrich, D., McKenzie, J.A., \& Song, H. (1983). Origin of calcite in syntectonic veins as determined from carbone-isotope ratios: Geology, 11, 547-551.

Doglioni, C. (1991). A proposal for the kinematic modelling of W-dipping subductions - Possible applications to the Tyrrhenian-Apennines system: Terra Nova, 3 (4), 423-434.

Doglioni, C., Mongelli, F., \& Pialli, G. (1998). Boudinage of the Alpine belt in the Apenninic back-arc: Mem. Soc. Geol. Ital., 52, 457-468.

Donelick, R.A., O'Sullivan, P.B., \& Ketcham, R.A. (2005). Apatite fission track analysis: Reviews in Mineralogy and Geochemistry, 58 (1), 49-94, doi:10.2138/rmg.2005.58.3.

Emery, D., \& Robinson, A.G. (1993). Inorganic Geochemistry: Applications to Petroleum Geology: Blackwell, Oxford, 254 pp.

Engelder, T. (1984). The role of pore water circulation during the deformation of foreland fold and thrust belts: Journal of Geophysical Research, 89, 4319-4325.

Evans, M.A., \& Elmore, R.D. (2006). Fluid control of localized mineral domains in limestone pressure solution structures: J. Struct. Geol., 28, 284-301.

Ferket, H., Guilhaumou, N., Roure, F., \& Swennen, R. (2011). Insights from fluid inclusions, thermal and PVT modelling for paleo-burial and thermal reconstruction of the Córdoba petroleum system (NE Mexico): Marine and Petroleum Geology, 28 (4), 936-958.

Friedman, I., \& O'Neil, J.R. (1977). Compilation of stable isotope fractionation factors of geochemical interest, In: Fleisher, M., ed., Data of Geochemistry (6th ed.): U.S. Geological Survey Professional Paper 440-KK, 117 p.

Galadini, F., Messina, P., Giacco, B. \& Sposato, A. (2003). Early uplift history of the Abruzzi Apennines (Central Italy): available geomorphological constraints: Quat. Int., 101-102, 125-135.

Galadini, F., \& Messina, P. (2004). Early-Middle Pleistocene eastward migration of the Abruzzi Apennine (central Italy) extensional domain: J. Geodyn., 37, 57-81.

Galluzzo, F., \& Santantonio, M. (2002). The Sabina Plateau: a new element in the Mesozoic palaeogeography of Central Apennines: Boll. Soc. Geol. It., vol. spec. n. 1,561-588.

Ghisetti, F. \& Vezzani, L. (1986). Assetto geometrico ed evoluzione strutturale della catena del Gran Sasso tra Vado di Siella e Vado di Corno: Boll. Soc. Geol. It., $105,131-171$. 
Ghisetti, F. (1987). Mechanisms of thrust faulting in the Gran Sasso chain, Central Apennines, Italy: Journal of Structual Geology, 9, 955-967.

Ghisetti, F. \& Vezzani, L. (1991). Thrust belt development in the Central Apennines (Italy): northward polarity of thrusting and out-of-sequence deformations in the Gran Sasso chain: Tectonics, 10, 904-919.

Ghisetti F., Barchi M., Bally A.W., Moretti I., \& Vezzani L. (1993a). Conflicting balanced sections across the central Apennines: Problems and implications: In A.M. Spencer (ed.), Generation, accumulation, and production of Europe's hydrocarbons. Special Publication of the European Association of Petroleum Geoscientists, 3, 219-231.

Ghisetti, F., Vezzani, L., \& Follador, U. (1993b). Transpressioni destre nelle zone esterne dell'Appennino centrale: Geologica Romana, 29, 73-95.

Ghisetti, F. \& Vezzani, L. (1997). Interfering paths of deformation and development of arcs in the fold-and-thrust belt of the Central Apennines (Italy): Tectonics, 16, 523-536.

Ghisetti, F. \& Vezzani, L. (1999). Depths and modes of Pliocene-Pleistocene crustal extension of the Apennines (Italy): Terra Nova, 11, 67-72.

Ghisetti, F., Kirschner, D.L., Vezzani, L., \& Agosta, F. (2001). Stable isotope evidence for contrasting paleofluid circulation in thrust faults and normal faults of the central Apennines, Italy: Journal of Geophysical Research, 106, 88118825.

Giraudi, C. \& Frezzotti, M. (1997). Late Pleistocene glacial events in the Central Apennines, Italy. Quaternary Research, 48, 280-290.

Goldstein, R.H. (1990). Petrographic and geochemical evidence for origin of paleospeleothems, New Mexico: Implications for the application of fluid inclusions to studies of diagenesis: J. Sed. Petrol. 60, 282-292.

Goldstein, R.H., Anderson, J.E., \& Bowmann, M.W. (1991). Diagenetic responses to sea-level change: integration of field, stable-isotope, paleosol, paleokarst, fluid inclusion and cement stratigraphy research to determine history and magnitude of sea-level fluctuation: in Franseen, E.K., Watney, W.L., Kendall, C.G.St.C., and Ross, W., eds., Sedimentary Modeling: Computer Simulations and Methods for Improved Parameter Definition: Kansas Geological Survey Bulletin, 233, 139-162. 
Granado, P., \& Ruh, J.B. (2019). Numerical modelling of inversion tectonics in foldand-thrust belts: Tectonophysics, 763, 14-29.

Graveleau, F., Malavieille, J., \& Dominguez, S. (2012). Experimental modelling of orogenic wedges: a review: Tectonophysics, 538-540, 1-66.

Gregg, J.M., \& Sibley, D.F. (1984). Epigenetic dolomitization and the origin of xenotopic dolomite texture: J. Sediment. Petrol. 54, 907-931.

Hausegger, S., Kurz, W., Rabitsch, R., Kiechl, E., \& Brosch, F.J. (2010). Analysis of the internal structure of a carbonate damage zone: implications for the mechanisms of fault breccia formation and fluid flow: J. Struct. Geol., 32 (9), 1349-1362.

Hoefs, J. (1997). Stable Isotope Geochemistry: Springer-Verlag, Berlin, 200 p.

Hohenberg, C.M., Thonnard, N., \& Meshik, A. (2002). Active capture and anomalous adsorption: new mechanisms for the incorporation of heavy noble gases. Meteorit. Planet. Sci., 37, 257-267.

Hudson, J.D. (1977). Stable isotopes and limestone lithification: J. Geol. Soc. London, 133, 637-660.

Konstantinovskaya, E.A., \& Malavieille, J. (2005). Accretionary orogens: Erosion and exhumation: Geotectonics, 39, 69-86.

Konstantinovskaya, E., \& Malavieille, J. (2011). Thrust wedges with décollement levels and syntectonic erosion: a view from analogue models: Tectonophysics, $502(3-4)$,

336-350.

Land, L.S. (1980). The isotopic and trace element geochemistry of dolomite: the state of the art: In: Zenger, D.H., Dunham, J.B., Ethington, R.L. Eds., Concepts and Models of Dolomitization. Spec. Publ.-SEPM, 28, 87-110.

Laubach, S.E., \& Ward, M.W. (2006). Diagenesis in porosity evolution of openingmode fractures, Middle Triassic to Lower Jurassic la Boca Formation, NE Mexico: Tectonophysics, 419, 75-97.

Laubach, S.E., Eichhubl, P., Hilgers, C., \& Lander, R.H. (2010). Structural diagenesis: Journal of Structural Geology, 32 (12), 1866-1872, doi:10.1016/j.jsg.2010.10.001.

Leah, H., Fondriest, M., Lucca, A., Storti, F., Balsamo, F., and Di Toro, G. (2018). Coseismic extension recorded within the damage zone of the Vado di Ferruccio 
Thrust Fault, Central Apennines, Italy. Journal of Structural Geology, 114, 121 138.

Lena, G., Barchi, M.R., Alvarez, W., Felici, F., \& Minelli, G. (2015). Mesostructural analysis of S-C fabrics in a shallow shear zone of the Umbria-Marche Apennines (Central Italy): In, Faulkner, D.R., Mariani, E. \& Mecklenburgh, J. Eds. Rock Deformation from Field, Experiments and Theory: A Volume in Honour of Ernie Rutter. Geological Society, London, Special Publications, 409, 149-166. http://dx.doi.org/10.1144/SP409.10.

Liotta, D., Cernobori, L., \& Nicolich, R. (1998). Restricted rifting and its coexistence with compressional structures; results from the CROP 3 traverse (Northern Apennines, Italy): Terra Nova, 10, 16-20.

Lucca, A., Storti, F., Molli, G., Muchez, P., Schito, A., Artoni, A., Balsamo, F., Corrado, S., \& Salvioli Mariani, E. (2018). Seismically enhanced hydrothermal plume advection through the process zone of the Compione extensional Fault, Northern Apennines, Italy: GSA Bulletin, 131 (3-4), 547-571, doi: https://doi.org/10.1130/B32029.1

Kirschner, D.L., \& Kennedy, L. (2001). Limited syntectonic flow in carbonate-hosted thrust faults of the Front Ranges, Canadian Rockies, inferred from stable isotope data and structures: J. Geophys. Res., 106, 8827-8840.

Machel, H.G. (1985). Cathodoluminescence in calcite and dolomite and its chemical interpretation: Geoscience Canada, 12, 139-147.

Machel, H.G. (2004). Concepts and models of dolomitization - A critical reappraisal: In C. Braithwaite, G. Rizzi, and G. Darke, eds., The geometry and petrogenesis of dolomite hydrocarbon reservoirs: Geological Society (London) Special Publication, 235, 7-63.

Malinverno, A., \& Ryan, W.B.F. (1986). Extension in the Tyrrhenian Sea and shortening in the Apennines as result of arc migration driven by sinking of the lithosphere: Tectonics, 5, 227-245.

Marini, M., Milli, S., Ravnås, R. \& Moscatelli, M. (2015). A comparative study of confined vs. semi-confined turbidite lobes from the Lower Messinian Laga Basin (Central Apennines, Italy): implications for assessment of reservoir architecture: Marine and Petroleum Geology, 63, 142-165. 
Mattei, M., Funiciello, R., \& Kissel, C. (1995). Paleomagnetic and structural evidence for Neogene block rotations in the Central Apennines, Italy: Journal of Geophysical Research, 100, 863-883

McArthur, J.M., Howarth, R.J., \& Shields, G.A. (2012). Strontium isotope stratigraphy. In: Gradstein, F.M. (Ed.), The Geologic Time Scale. Elsevier Science Limited, pp. 127-144.

Mele, G., Sandvol, E., \& Cavinato, G.P. (2006). Evidence of crustal thickening beneath the central Apennines (Italy) from teleseismic receiver functions: Earth and Planetary Science Letters, 249, 425-435.

Mozafari, M., Swennen, R., Muchez, P., Vassilieva, E., Balsamo, F., Storti, F., Pironon, J., \& Taberner, C. (2017). Origin of the saline paleofluids in faultdamage zones of the Jabal Qusaybah Anticline (Adam Foothills, Oman): constrains from fluid inclusions geochemistry: Marine and Petroleum Geology, 86, 537-546.

Muchez, P., Slobodnik, M., Viaene, W.A., \& Keppens, E. (1995). Geochemical constraints on the origin and migration of palaeofluids at the northern margin of the Variscan foreland, southern Belgium: Sedimentary Geology, 96, 191-200.

Murgia, M.V., Ronchi, P., \& Ceriani, A. (2004). Dolomitization processes and their relationships with the evolution of an orogenic belt (Central Apennines and periAdriatic foreland, Italy): in Swennen, R., Roure, F., \& Granath, J.W. eds. Deformation, fluid flow, and reservoir appraisal in foreland fold and thrust belts: AAPG Hedberg Series, no. 1, 277-294.

Nelson, C.S., \& Smith, A.M. (1996). Stable oxygen and carbon isotope compositional fields for skeletal and diagenetic components in New Zealand Cenozoic nontropical carbonate sediments and limestones: a synthesis and review: New Zealand Journal of Geology and Geophysics, 39, 93-107.

Pace, P., Di Domenica, A., \& Calamita, F. (2014). Summit low-angle faults in the Central Apennines of Italy: Younger-on-older thrusts or rotated normal faults? Constraints for defining the tectonic style of thrust belts: Tectonics, 33, 756785.

Pace, P., \& Calamita, F. (2015). Coalescence of fault-bend and fault-propagation folding in curved thrust systems: an insight from the Central Apennines, Italy: Terra Nova, 27, 175-183. 
Park, W.G., \& Schott, E.H. (1968). Stylolites: Their nature and origin: Journal of Sedimentary Petrology, 38, 175-191.

Patacca, E., Sartori, R., \& Scandone, P. (1990). Tyrrhenian Basin and Apenninic arc: Kinematic relations since late Tortonian times: Mem. Soc. Geol. It., 45, 425451.

Patacca, E., Scandone, P., Di Luzio, E., Cavinato, G.P., \& Parotto, M. (2008). Structural architecture of the central Apennines: interpretation of the CROP 11 seismic profile from the Adriatic coast to the orographic divide: Tectonics, 27, TC3006, doi:10.1029/2005TC001917.

Pierantoni, P., Deiana, G., \& Galdenzi, S. 2013. Stratigraphic and structural features of the

Sibillini Mountains (Umbria-Marche Apennines, Italy): Ital. J. Geosci., 132 (3), $497-$

520.

Pinti, D.L., \& Marty, B. (1995). Noble gases in crude oils from the Paris Basin, France: Implications for the origin of fluids and constraints on oil-water-gas interactions: Geochimica et Cosmochimica Acta, 59, 3389-3404.

Principi, G., \& Treves, B. (1984). II sistema corso-appennino come prisma d'accrezione. Riflessi sul problema generale del limite Alpi-Appennino: Mem. Soc. Geol. It., 28, 529-576.

Ramsay, J.G. (1980). Shear zone geometry: a review: J. Struct. Geol., 2, 83-99.

Rasbury, E.T., \& Cole, J.M. (2009). Directly dating geologic events: U-Pb dating of carbonates: Reviews of Geophysics, 47, RG3001.

Ronchi, P., Jadoul F. \& Savino R. (2004). Quaternary dedolomitization along fracture systems in a Late Triassic dolomitized platform (western Southern Alps, Italy): Carbonates and Evaporites, 19 (1), 51-66.

Ronchi, P., Di Giulio, A., Ceriani, A., \& Scotti, P. (2010). Contrasting fluid events giving rise to apparently similar diagenetic products; late-stage dolomite cements from the Southern Alps and Central Apennines, Italy: in, Van Buchem, F.S.P., Gerds, K.D., \& Esteban, M. eds, Mesozoic and Cenozoic Carbonate Systems of the Mediterranean and the Middle East: Stratigraphic and Diagenetic Reference Models. Geological Society, London, Special Publications, 329, 397-413. 
Roure, F., Swennen, R., Schneider, F., Faure, J.L., Ferket, H., Guilhaumou, N., Osadetz, K., Robion, P., \& Vandeginste, V. (2005). Incidence and importance of tectonics and natural fluid migration on reservoir evolution in foreland foldand-thrust belts: In: Brosse, E. (Ed.), Oil and Gas Science and Technology, Oil and Gas Science and Technology. Revue de I'IFP 60, 67-106.

Royden, L. (1988). Flexural behaviour of the continental lithosphere in Italy: Constraints imposed by gravity and deflection data: Journal of Geophysical Research, 93, 7747-7766.

Royden, L., \& Faccenna, C. (2018). Subduction Orogeny and the Late Cenozoic Evolution of the Mediterranean Arcs: Annu. Rev. Earth Planet. Sci., 46, 261-89.

Rusciadelli, G., Viandante, M.G., Calamita, F., \& Cook A.C. (2005). Burialexhumation history of the central Apennines (Italy), from the foreland to the chain building: thermochronological and geological data: Terra Nova, 17, 560572.

Sage, L., Mosconi, A., Moretti, I., Riva, E., \& Roure, F. (1991). Cross section balancing in the central Apennines: An application of LOCACE: AAPG, 75 (4), 832-844.

Sani, F., Del Ventisette, C., Montanari, D., Coli, M., Nafissi, P., \& Piazzini, A. (2004). Tectonic evolution of the internal sector of the Central Apennines, Italy: Marine and Petroleum Geology, 21, 1235-1254.

Santantonio, M. (1993). Facies associations and evolution of pelagic carbonate platform/basin systems: examples from the Italian Jurassic: Sedimentology 40, 1039-1067.

Satolli, S., Speranza, F., \& Calamita F. (2005). Paleomagnetism of the Gran Sasso range salient (central apennines, Italy): Pattern of orogenic rotations due to translation of a massive carbonate indenter: Tectonics, 24, 1-22.

Scisciani, V., Tavarnelli, E., \& Calamita, F. (2002). The interaction of extensional and contractional deformations in the outer zones of the Central Apennines, Italy: Journal of Structural Geology, 24, 1647-1658, doi: 10.1016/S01918141(01)00164-X.

Servizio Geologico d'Italia (1963). Carta geologica d'Italia, Foglio n. 140. Teramo, Roma. 
Sibson, R.H. (1981). Fluid flow accompanying faulting: Field evidence and models: in Simpson, D.W., and Richards, P.G., cds., Earthquake prediction-An international review: American (Gophysical Union Monograph, Maurice Ewing Series, 4, 593-603.

Sibson, R.H. (1990). Conditions for fault-valve behaviour: In: Geological Society of London, Special Publication, 54, 15-28.

Smeraglia, L., Berra, F., Billi, A., Boschi, C., \& Carminati, E. (2016). Origin and role of fuids involved in the seismic cycle of extensional faults in carbonate rocks: EPSL, 450, 292-305.

Smeraglia, L., Aldega, L., Billi, A., Carminati, E., Di Fiore, F., Gerdes, A., Albert, R., Rossetti, F., \& Vignaroli, G. (2019). Development of an intrawedge tectonic mélange by out of-sequence thrusting, buttressing, and intraformational rheological contrast, Mt. Massico ridge, Apennines, Italy: Tectonics, 38, 12231249, https://doi.org/10.1029/2018TC005243

Speranza, F., Adamoli, L., Maniscalco, R., \& Florindo F. (2003). Genesis and evolution of a curved mountain front: paleomagnetic and geological evidence from the Gran Sasso range (central Apennines, Italy): Tectonophysics, 362, 183-197.

Storti, F., \& McClay, K. (1995). Influence of syntectonic sedimentation on thrust wedges in analogue models: Geology, 23, 999-1002.

Storti, F., Salvini, F., \& McClay, K. (2000). Synchronous and velocity-partitioned thrusting and thrust polarity reversal in experimentally produced, doublyvergent thrust wedges: implications for natural orogens: Tectonics, 19 (2), 378396.

Storti, F., Balsamo, F., Mozafari, M., Koopman, A., Swennen, R., \& Taberner, C. (2018). Syn-Contractional Overprinting Between Extension and Shortening Along the Montagna Dei Fiori Fault During Plio-Pleistocene Antiformal Stacking at the Central Apennines Thrust Wedge Toe: Tectonics, 37 (10), 3690-3720, https://doi.org/10.1029/2018TC005072.

Tesei, T., Collettini, C., Viti, C., \& Barchi, M.R. (2013). Fault architecture and deformation mechanisms in exhumed analogues of seismogenic carbonatebearing thrusts: Journal of Structural Geology, 55, 167-181. 
Tiberti, M.M., Orlando, L., Di Bucci, D., Bernabini, M., \& Parotto, M. (2005). Regional gravity anomaly map and crustal model of the Central-Southern Apennines (Italy): Journal of Geodynamics, 40, 73-91.

Torgersen, T., \& Clarke, W.B. (1985). Helium accumulation in groundwater I: An evaluation of sources and the continental flux of ${ }^{4} \mathrm{He}$ in the Great Artesian Basin, Australia: Geochimica et Cosmochimica Acta, 49, 1211-1218.

Torgersen, T., \& Ivey, G.N. (1985). Helium accumulation in groundwater II: A model for the accumulation of the crustal $4 \mathrm{He}$ degassing flux: Geochimica et Cosmochimica Acta, 49, 2445-2452.

Torgersen, T. (1989). Terrestrial helium degassing fluxes and the atmospheric helium budget: Implications with respect to the degassing processes of continental crust: Chemical Geology, 79, 1-14.

Tozer, R.S.J., Butler R.W.H., \& Corrado S. (2002). Comparing thin- and thickskinned thrust tectonics models of the Central Apennines, Italy: in Continental Collision and the Tectono-Sedimentary Evolution of Forelands, Stephan Mueller Spec. Publ. Ser., 1, 181-194, Eur. Geosci. Union, Strasbourg, France.

Veizer, J., Ala, D., Azmy, K., Bruckschen, P., Buhl, D., Bruhn, F., Carden, G.A.F., Diener, A., Ebneth, S., Godderis, Y., Jasper, T., Korte, C., Pawellek, F., Podlaha, O.G. \& Strauss, H. (1999) $.87 \mathrm{Sr} / 86 \mathrm{Sr}, \delta^{13} \mathrm{C}$ and $\delta^{18} \mathrm{O}$ evolution of Phanerozoic seawater: Chem. Geol., 161, 59-88.

Verges, J., \& Muñoz, J.A. (1990). Thrust sequences in the Southern Central Pyrenees: Bulletin de la Societe Geologique de France, VI(2)(8), 265-271 DOI: 10.2113/gssgfbull.VI.2.265.

Vezzani, L., Festa, A., \& Ghisetti, F.C. (2010). Geology and tectonic evolution of the Central-Southern Apennines, Italy: Geological Society of America Special Paper 469, 1-58.

Vilasi, N., Malandain, J., Barrier, L., Callot, J-P., Amrouch, K., Guilhaumou, N., Lacombe, O., Muska, K., Roure, F., and Swennen, R. (2009). From outcrop and petrographic studies to basin-scale fluid flow modelling: the use of the Albanian natural laboratory for carbonate reservoir characterisation: Tectonophysics, 474 (1-2), 367-392. 
Viola, G., Scheiber, T., Fredin, O., Zwingmann, H., Margreth, A. \& Knies, J. (2016). Deconvoluting complex structural histories archived in brittle fault zones: Nature Communications, 7, Article Number 13448, doi: 10.1038/ncomms 13448.

Warren, J. (2000). Dolomite: occurrence, evolution and economically important associations: Earth Science Reviews, 52, 1-81.

Wiltschko, D.V., Lambert, G.R., \& Lamb, W. (2009). Conditions during syntectonic vein formation in the footwall of the Absaroka Thrust Fault, Idaho-WyomingUtah fold and thrust belt: Journal of Structural Geology, 31, 1039-1057.

Woodcock, N.H., \& Mort, K. (2008). Classification of fault breccias and related fault rocks.

Geol. Mag., 145 (03), 435-440.

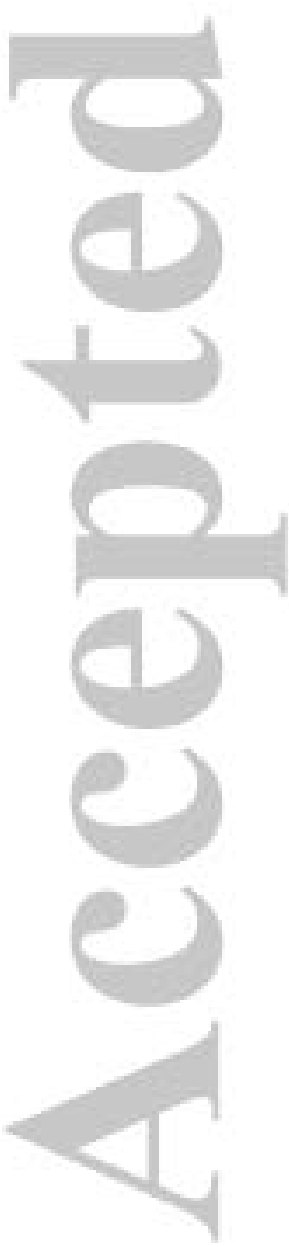




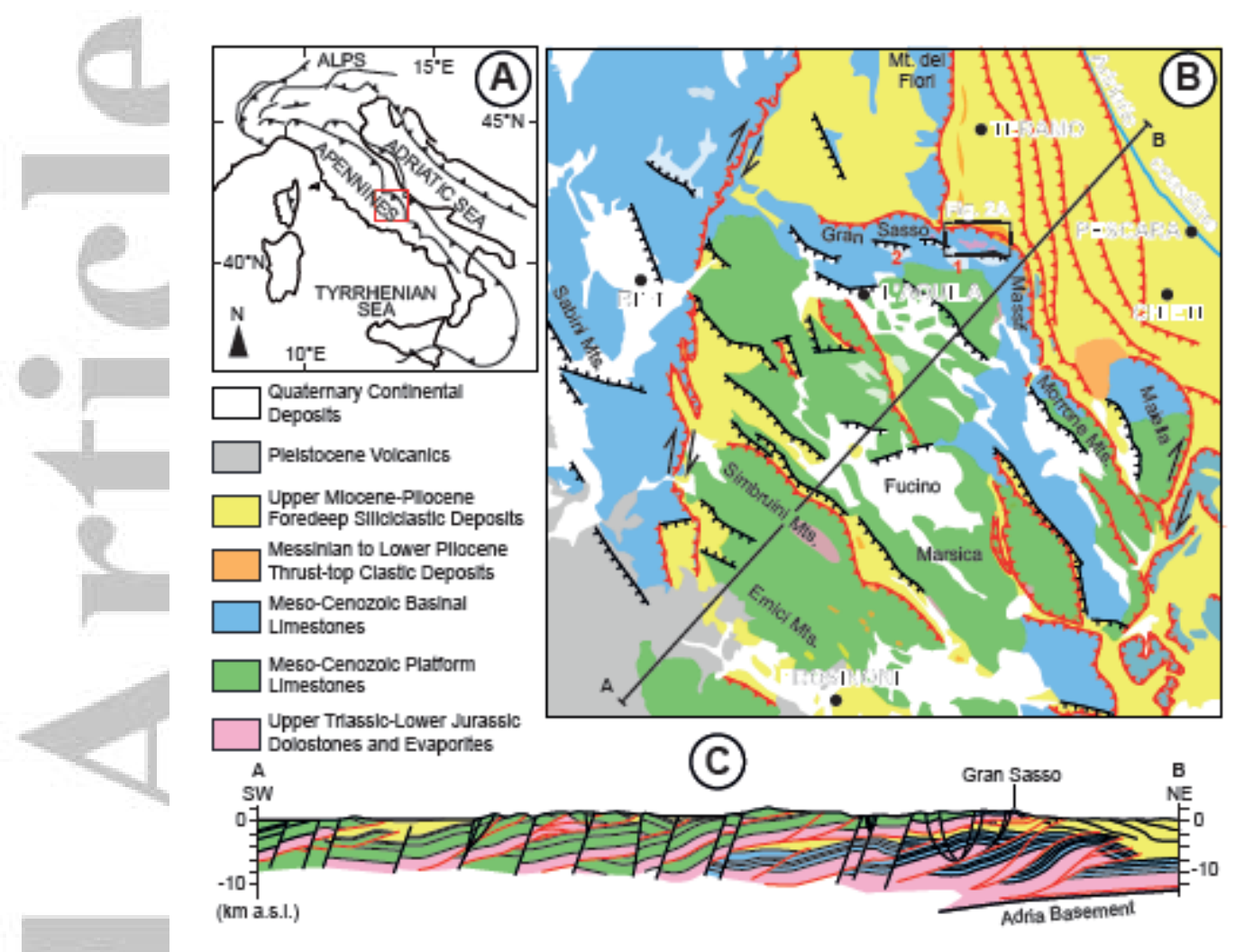

Figure 1. (A) Location of the study area, in the Central Apennines. (B) Tectonic sketch map of the Central Apennines showing the Gran Sasso Massif and other major thrust sheets overprinted by extensional faulting; arrows indicate transpressive lineaments, trace A-B refers to crosssection in C, red numbers indicate the extensional fault-bounded Campo Imperatore Basin (1) and Assergi Basin (2), and black dashed square indicates the location of Fig.2A. (C) Cross section of the Central Apennines orogenic wedge, adapted from Cosentino et al., 2010. 


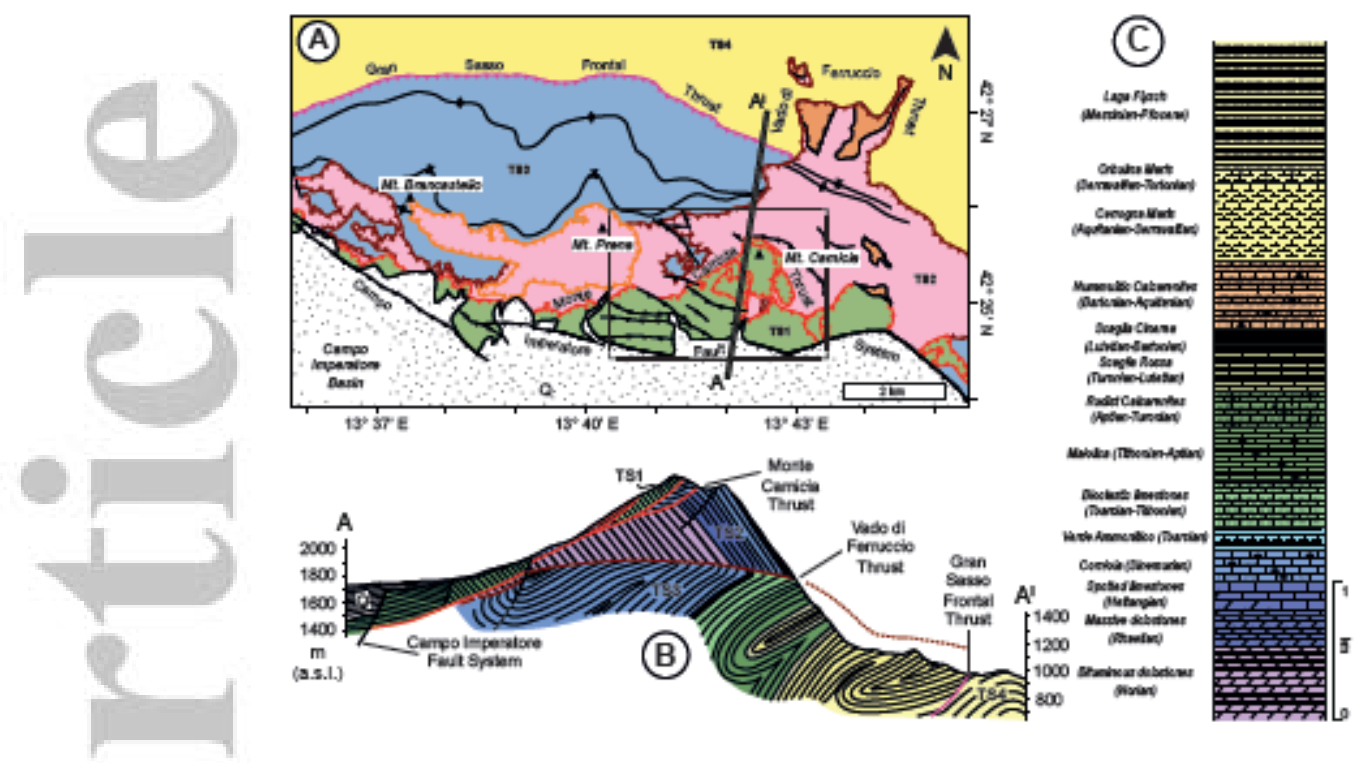

Figure 2 (A) Structural map showing the four thrust sheets and the main faults and folds in the north-eastern apex of the massif; trace A-A' corresponds to the cross-section in B; dashed black rectangle represents the study area. (B) Cross-section passing through Mt. Camicia showing the thrust sheets described in the text (adapted from Ghisetti \& Vezzani, 1986); (C) Simplified stratigraphic section of the study area. 

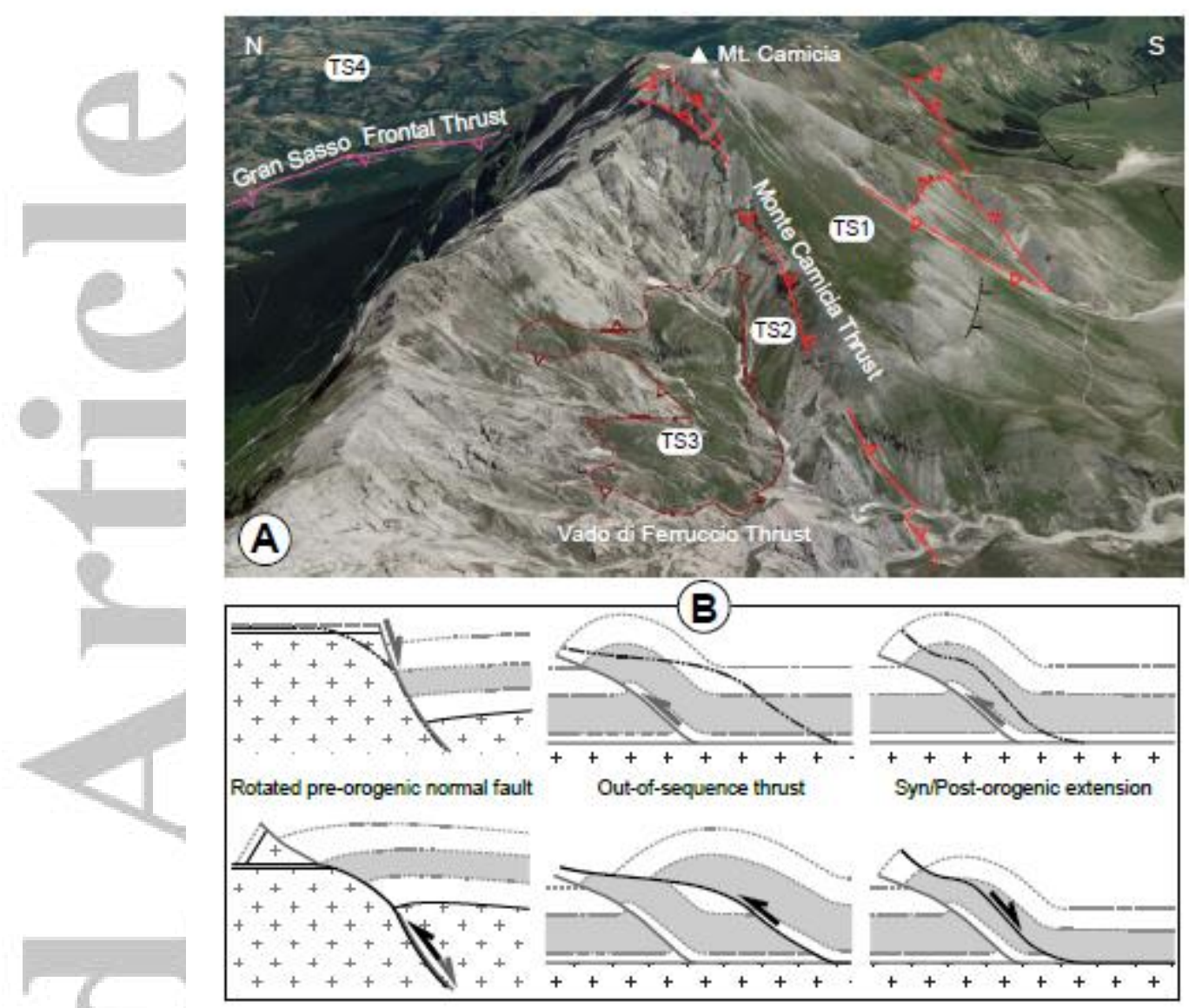

Figure 3. (A) Google Earth image, looking towards East, illustrating the topographic relief of the Mt. Camicia and linedrawings of the Monte Camicia, Vado di Ferruccio thrusts and Gran Sasso Frontal thrust; (B) Interpretations of low-angle faults showing younger over older rocks relationships in the Central Apennines (Pace et al., 2014; Ghisetti \& Vezzani, 1986; D'agostino et al., 1998). 


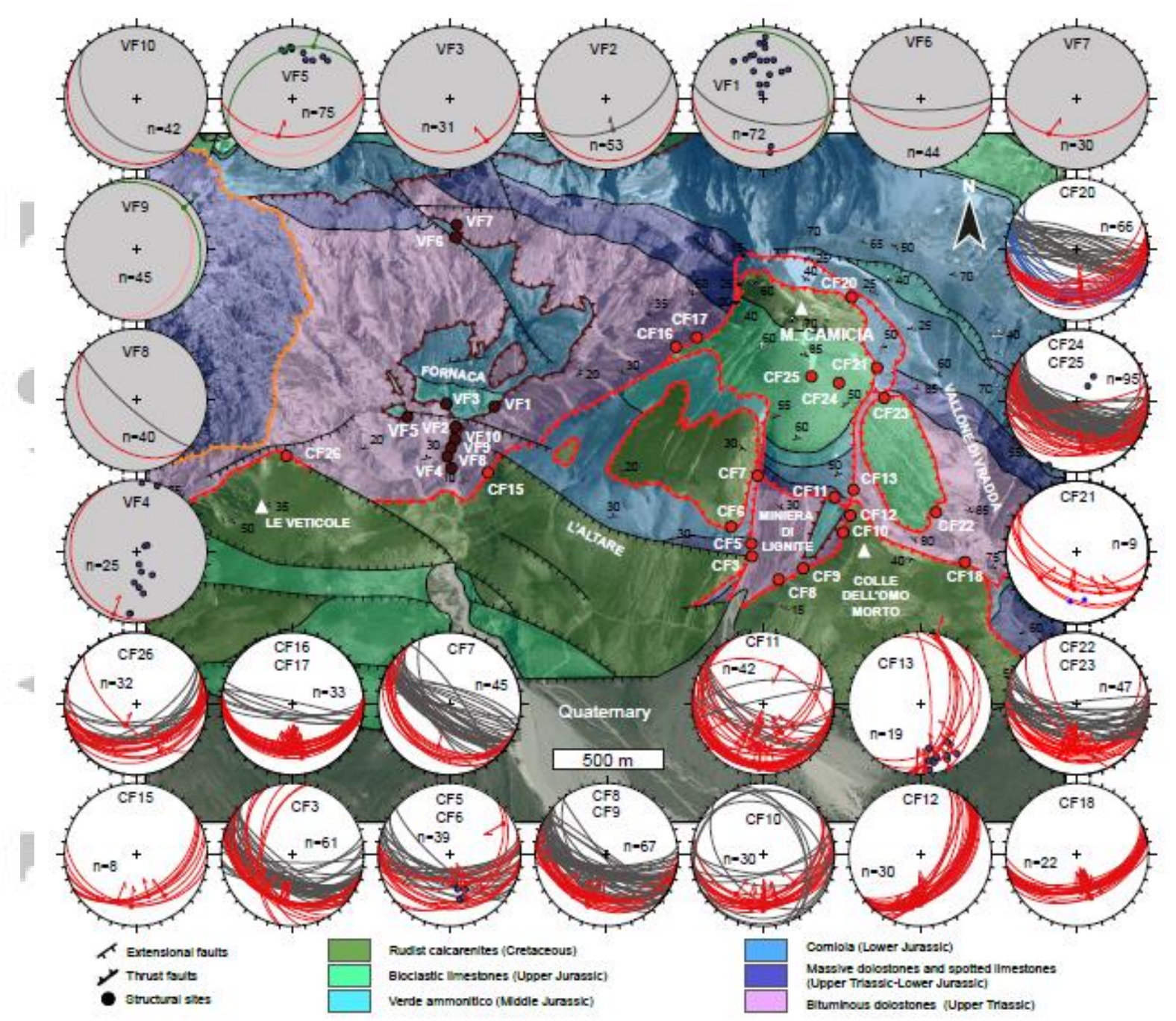

Figure 4. Aerial orthophoto showing lithostratigraphic units, thrusts, extensional faults and structural sites in the study area. Red for the Monte Camicia Thrust, purple for the Vado di Ferruccio Thrust and orange for the Monte Prena splay Thrust. In the stereographic projections, the great circles and slickenlines in red represent thrust surfaces and relative lineations, grey for tectonic stylolites, blue for bedding parallel stylolites, green for C' shear surfaces, pink for subsidiary thrust surfaces and blue dots correspond to poles to bedding. Stereonets with white background for the Monte Camicia Thrust and grey background for the Vado di Ferruccio Thrust. Only mean values are reported in the stereographic projections with grey background, i.e. contractional structures related to the Vado di Ferruccio Thrust (see Leah et al., 2018 for the whole dataset). 


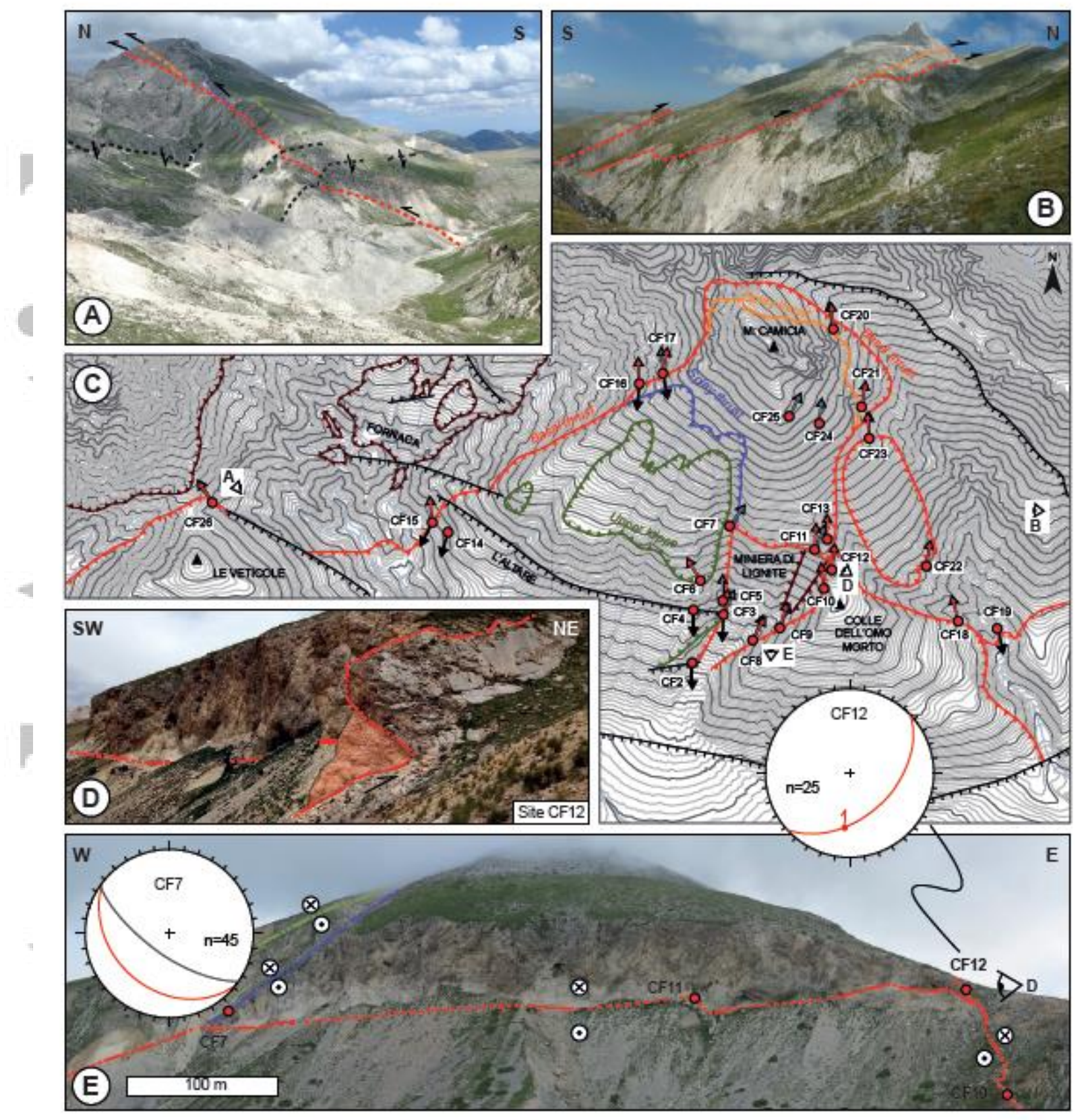

Figure 5. Annotated images of the Monte Camicia Thrust seen from the west $(A)$ and from east (B). The master basal slip surface is in red, minor splays are in orange, green and purple, while high-angle extensional faults are in black. Arrows indicate kinematics. (C) Architecture of the Monte Camicia Thrust and mean directions of the kinematics measured in the structural sites. Red arrows represent slickenlines on thrusts, grey arrows are orthogonal to the intersection line between $\mathrm{S}$ and $\mathrm{C}$ planes of thrusts and black arrows for slickenlines on extensional faults. "Eye" symbols indicate where images were acquired. (D) Image of Site CF12, where the Monte Camicia Thrust shows transpressional kinematics. (E) Image of the top of the Miniera di Lignite 
area, where the hanging wall acquires a lensoidal geometry. The splay thrust on the west, in Site CF7, shows southwest dipping planes while they are southeast dipping in the eastern part (Site CF12; D). Stereographic projections show average planes and slickenlines in the east and west sites. Grey for tectonic stylolites and red for thrust surfaces and slickenlines.

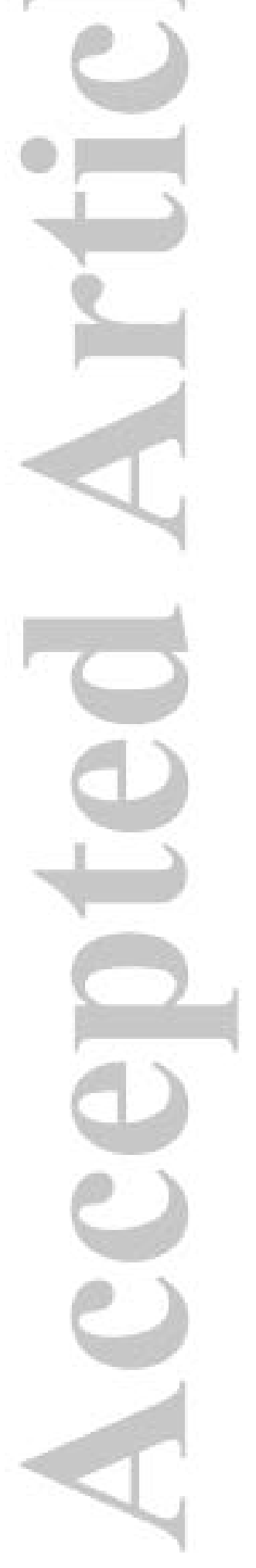



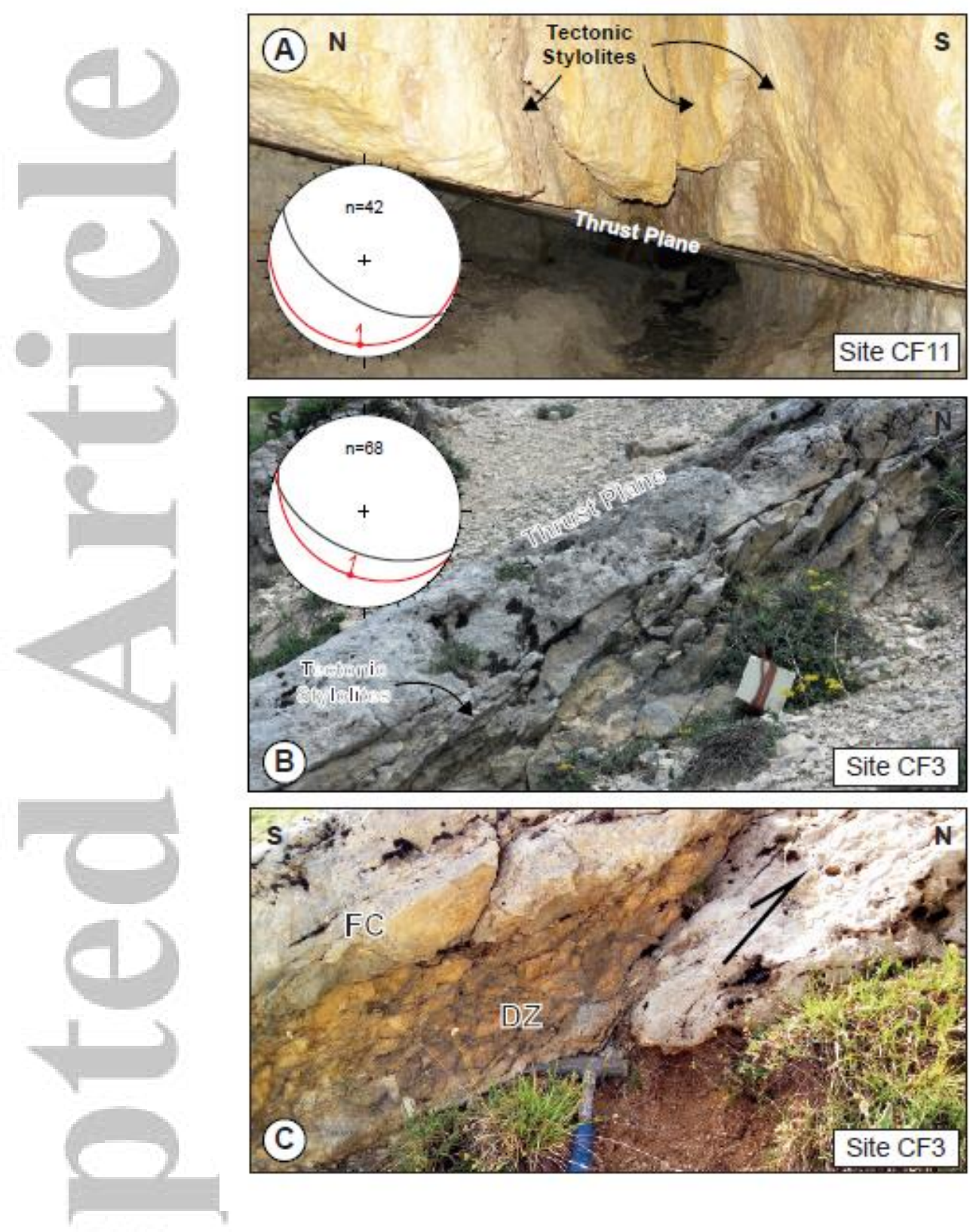

Figure 6. Images showing contractional structures of the Monte Camicia Thrust. (A) Fonte Grotte cave, Site CF11, showing sharp south dipping thrust surface with top-to-the north kinematics and high-angle south-southwest dipping tectonic stylolites in the hanging wall damage zone. (B) Western side of the Miniera di Lignite area, Site CF3, showing karstified fault core and tectonic pressure solution planes in the footwall damage zone that dip south-southwest and have a topto-the north-northeast transport direction. (C) Image acquired at the same site as B showing a subsidiary thrust which causes duplexing of the Thrust zone. Stereographic projections show average planes and slickenlines at the respective sites. Grey for tectonic stylolites and red for thrust surfaces and slickenlines. 

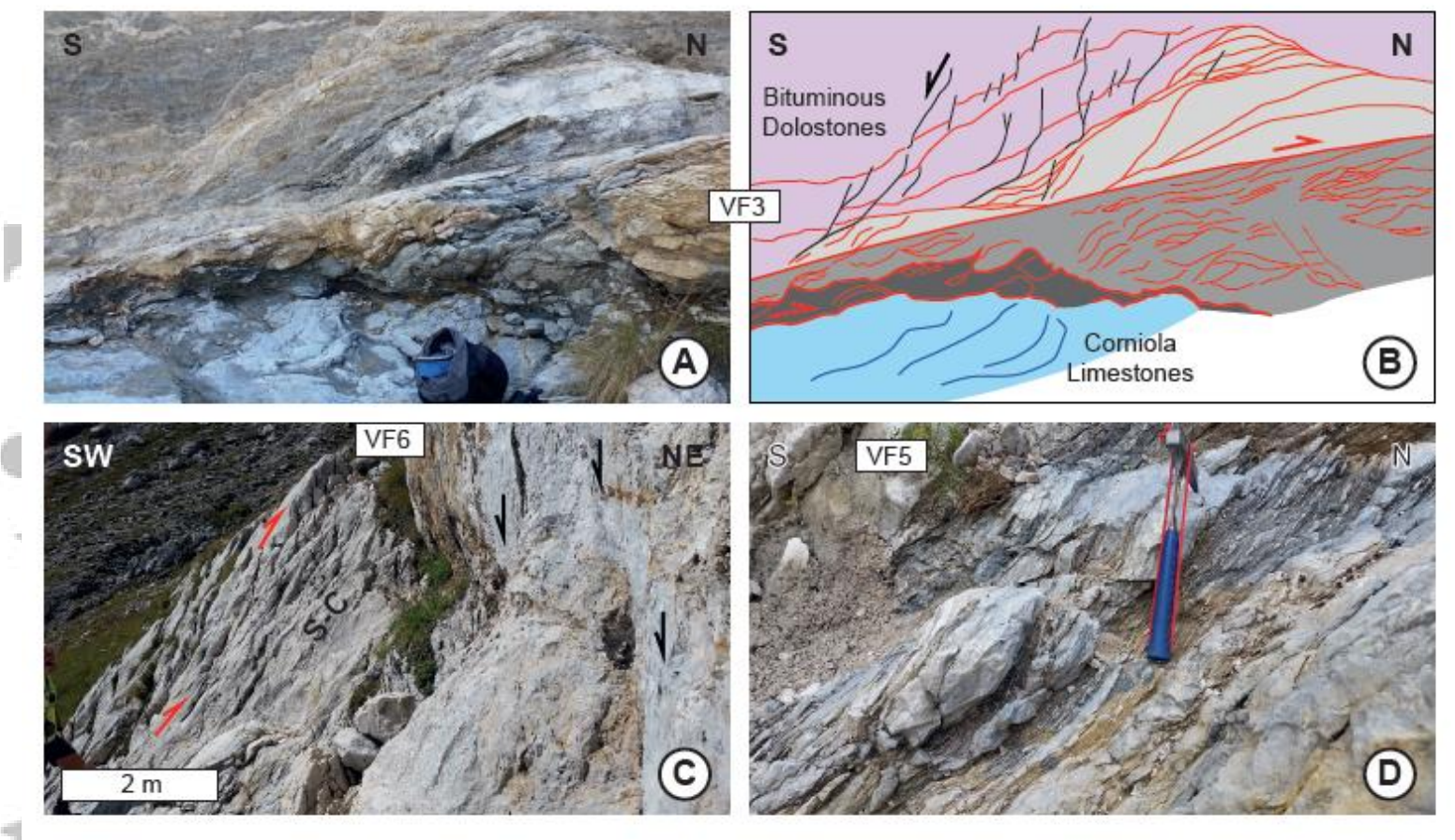

Figure 7. Image (A) and interpretive sketch (B) of the Vado di Ferruccio Thrust. The footwall damage zone is composed of folded Corniola thin beds, the fault core has a sharp upper boundary and pressure solution increases towards the base and the hanging wall damage zone comprises a zone of minor duplexing near the fault core and a zone intersected by extensional faults that sole down onto the fault core upper boundary. (C) NW-SE near vertical extensional fault cutting through the Vado di ferruccio Thrust. (D) The fault core is a foliated cataclasite. Here, in Site VF5, C' synthetic low-angle planes are well developed. 


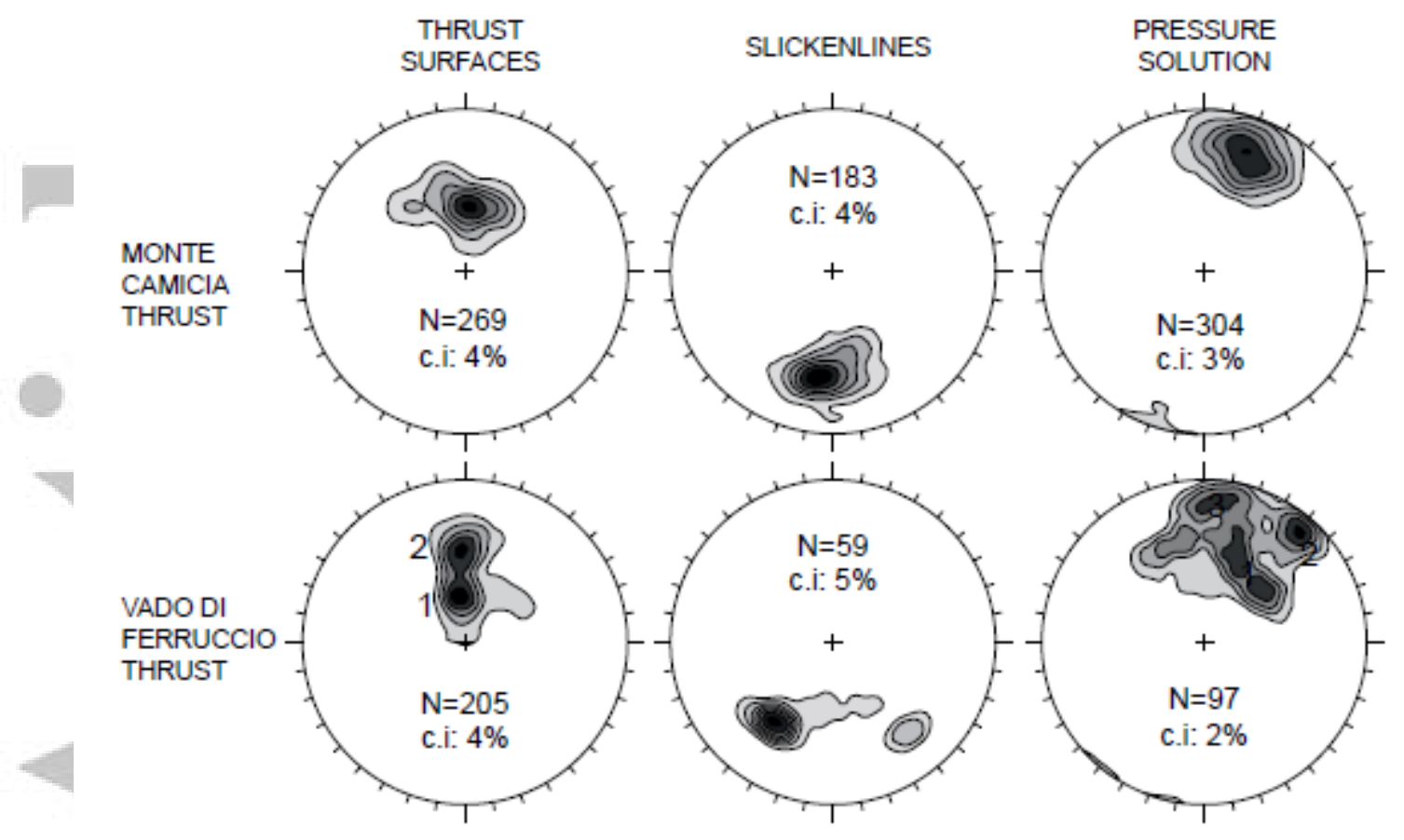

Figure 8. Stereographic projections of cumulative structural data of thrust surfaces, slickenlines and pressure solution planes collected along the Vado di Ferruccio and Monte Camicia thrusts. N and c.i. indicate number of data and the contouring interval, respectively. 


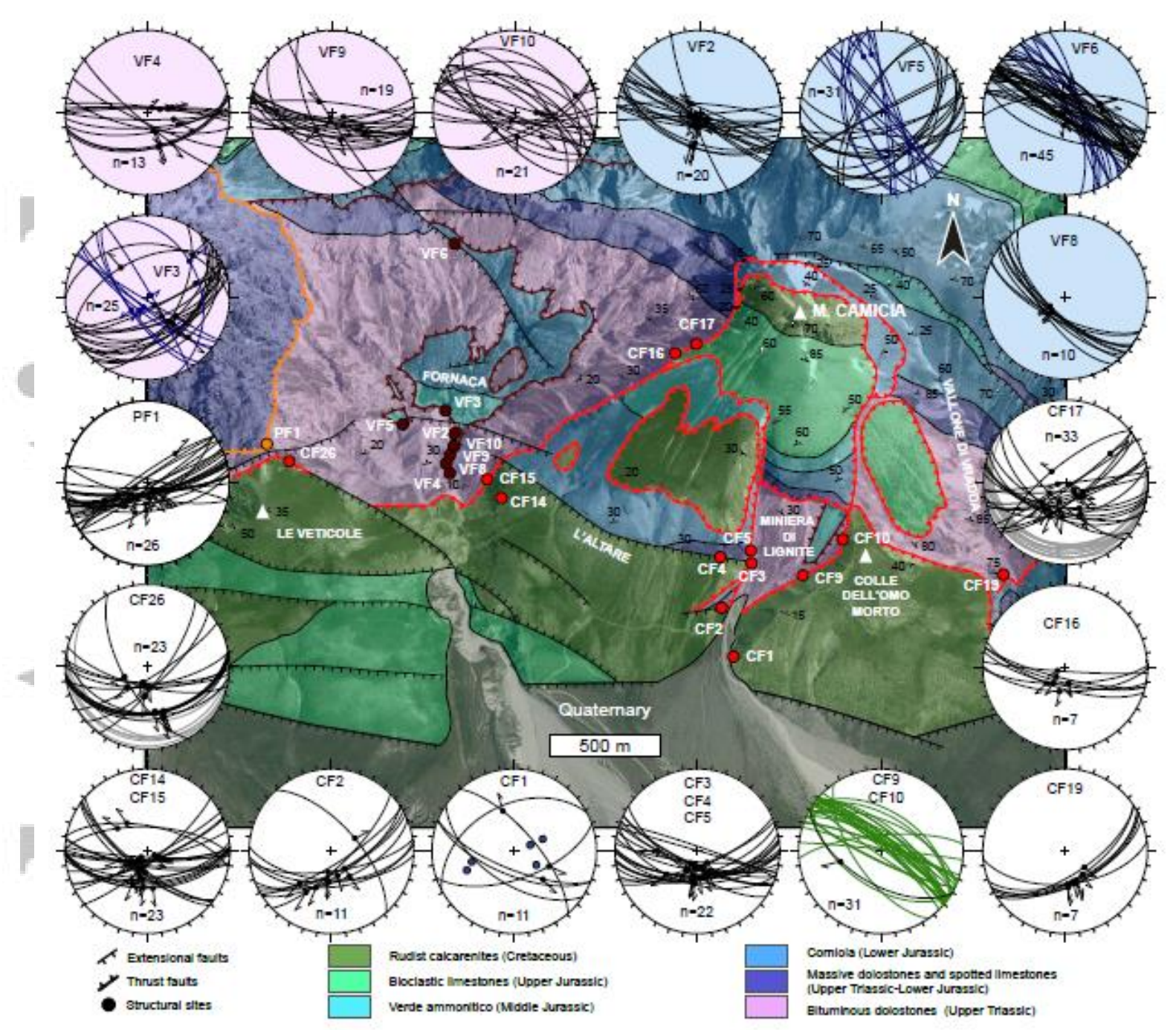

Figure 9. Aerial orthophoto showing lithostratigraphic units, thrusts, extensional faults and structural sites in the study area. Red for the Monte Camicia Thrust, purple for the Vado di Ferruccio Thrust and orange for the Monte Prena splay thrust. In the sterographic projections, black great circles and slickenlines for extensional faults, blue for NW-SE strike-slip faults, grey for low-angle tectonic stylolites, green for extensional joints in the Monte Camicia Thrust hanging wall damage zone and blue dots are poles to bedding planes. Stereographic projections with white background for Sites where extensional faults are in the hanging wall of the Monte Camicia Thrust while orange where extensional faults cut through it. Pink and blue backgrounds for Sites where extensional faults sole down onto and cut through the Vado di Ferruccio Thrust, respectively. 

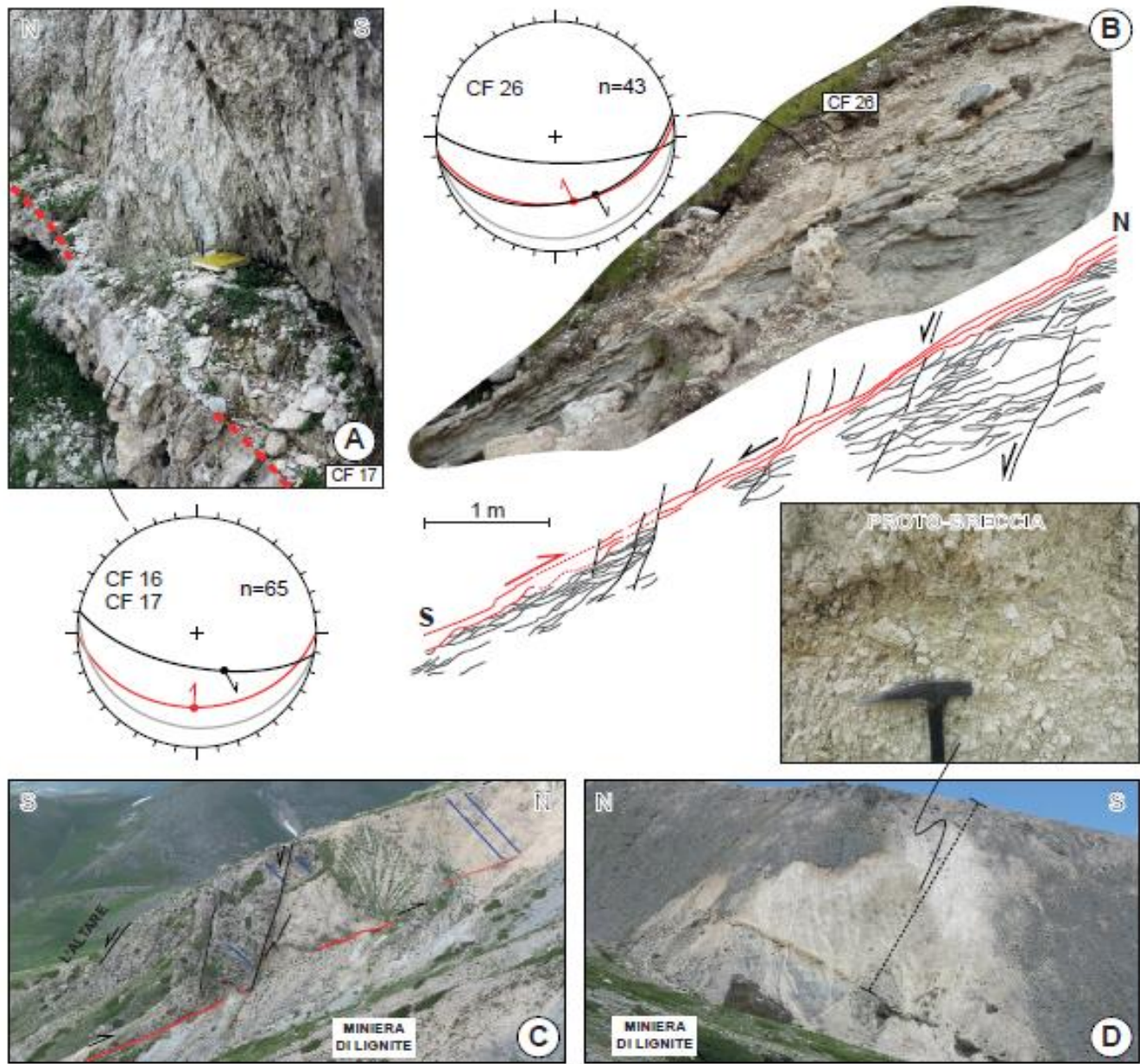

Figure 10. (A) Outcrop picture of south dipping extensional faults, shaded black lines, flattening down onto the Monte Camicia Thrust, shaded red lines, in the calcarenites near the top of Mt. Camicia, in Site CF17. (B) Image and interpretation of the Monte Camicia Thrust in Site CF26 where extensional reactivation is evident by the presence of extensional faults both falttening and cutting the thrust surface and by low-angle tectonic stylolites. (C) Image showing the western side of the Miniera di Lignite area where an extensional fault zone with metric offset (black lines) dissects the Monte Camicia Thrust (red lines); blue lines represent bedding. (D) Image showing the eastern side of the Miniera di Lignite area. Here, as in the footwall of the extensional fault zone in $\mathrm{C}$, the hanging wall of the Monte Camicia Thrust (brownish lineament in picture) is characterized by intense fracturing by high-angle joints causing proto-brecciation of the Calcarenites, as illustrated in the inset. 

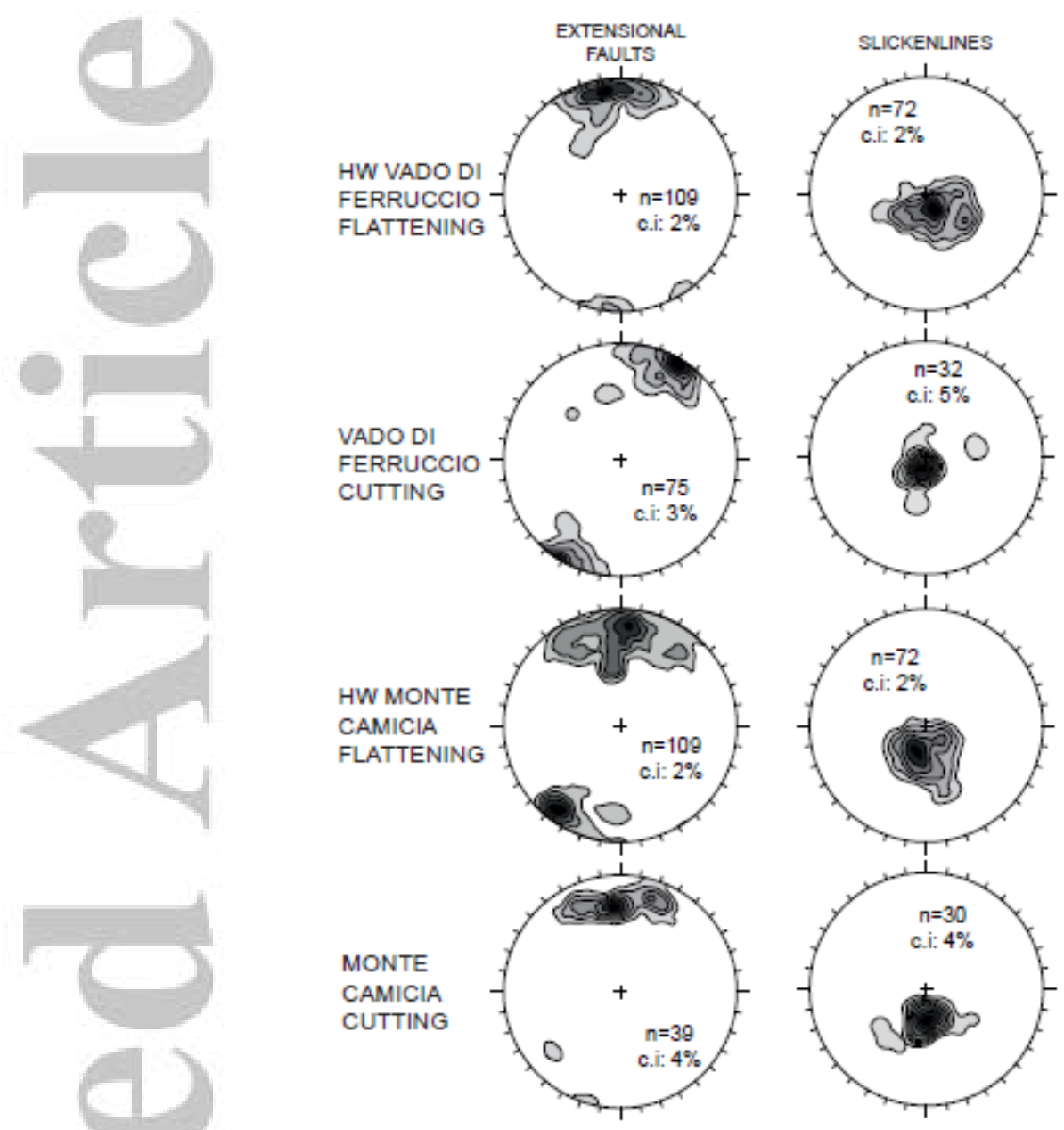

Figure 11. Stereographic projections of cumulative structural data of extensional fault planes and slickenlines flattening onto and cutting through the Vado di Ferruccio and the Monte Camicia thrusts. $\mathrm{N}$ and c.i. indicate number of data and the contouring interval, respectively. 

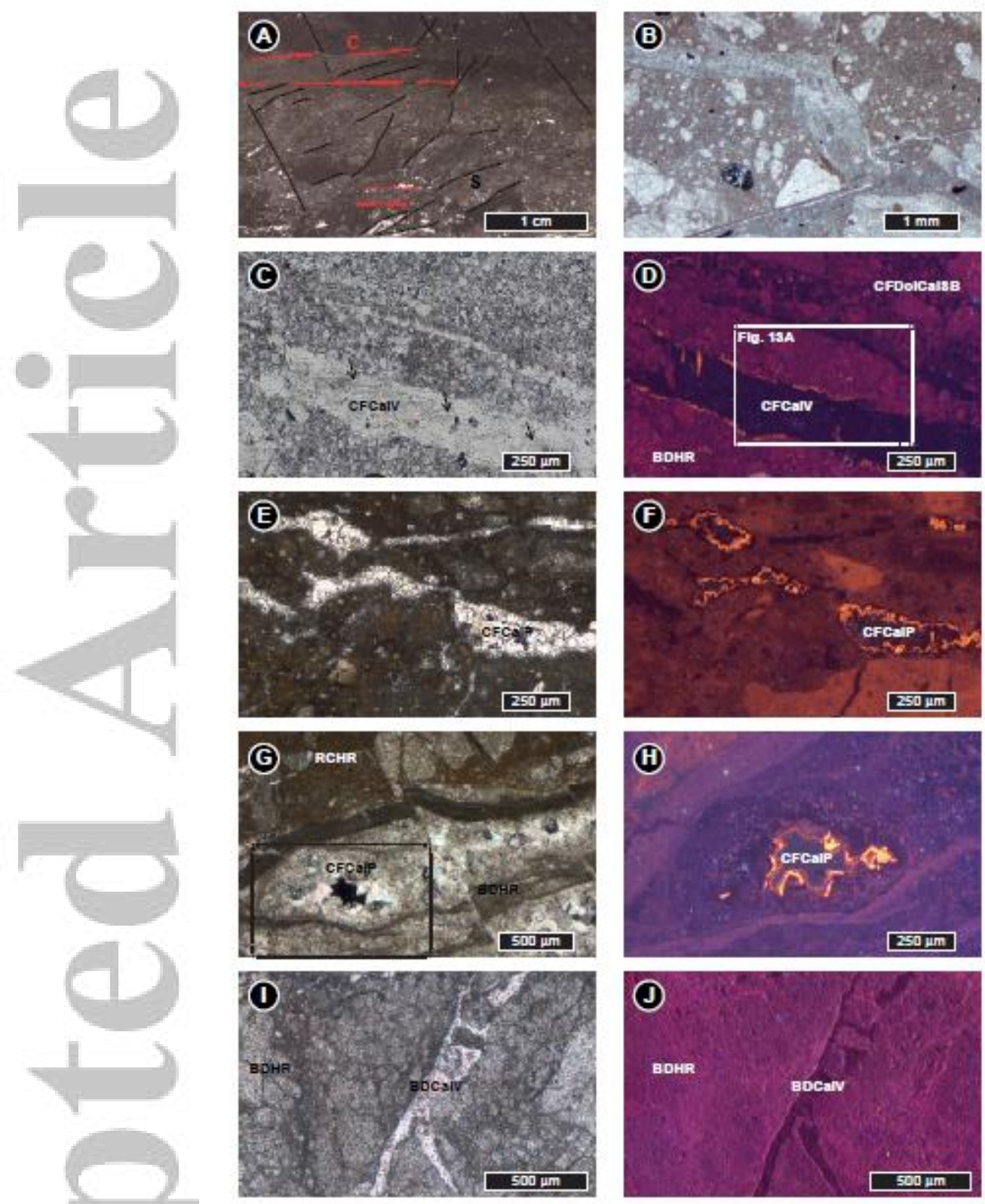

Figure 12. Petrography of the Monte Camicia Thrust. All images have top-to-the right shear sense. (A) Thin section scan of foliated cataclasite sampled in the fault core in Site CF26; highlighting S-C surfaces overprinted by high-angle extensional shear planes. (B) XPL image showing injection of vein of cataclastic material into the hanging wall damage zone and low-angle vein along the main thrusting surface; sampled in Site CF22. PPL (C) and (D) CL images illustrating a low-angle vein in the footwall damage zone cemented by non-luminescent-yellow CFCalV calcite. (E) PPL and (F) CL images of calcarenites sampled in the fault core in Site CF10 where microfractures subparallel to the thrust are cemented with dogtooth, non-luminescent- 
yellow zoned CFCalP calcite. (G) PPL and $(\mathrm{H}) \mathrm{CL}$ images showing dolostones interested by vuggy porosity below the fault core in Site CF9; vugs are cemented by dogtooth nonluminescent-yellow zoned calcite. (I) PPL and (J) CL images illustrating the non-luminescent BDCalV calcite high-angle vein (I-J) in the footwall damage zone in Site CF3.

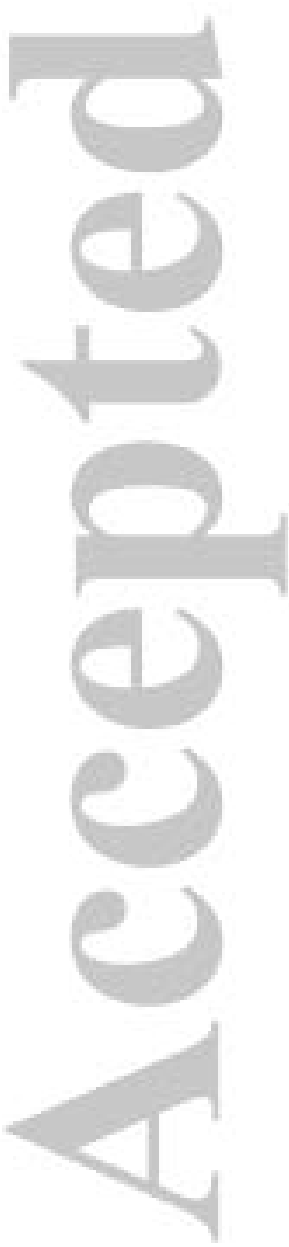



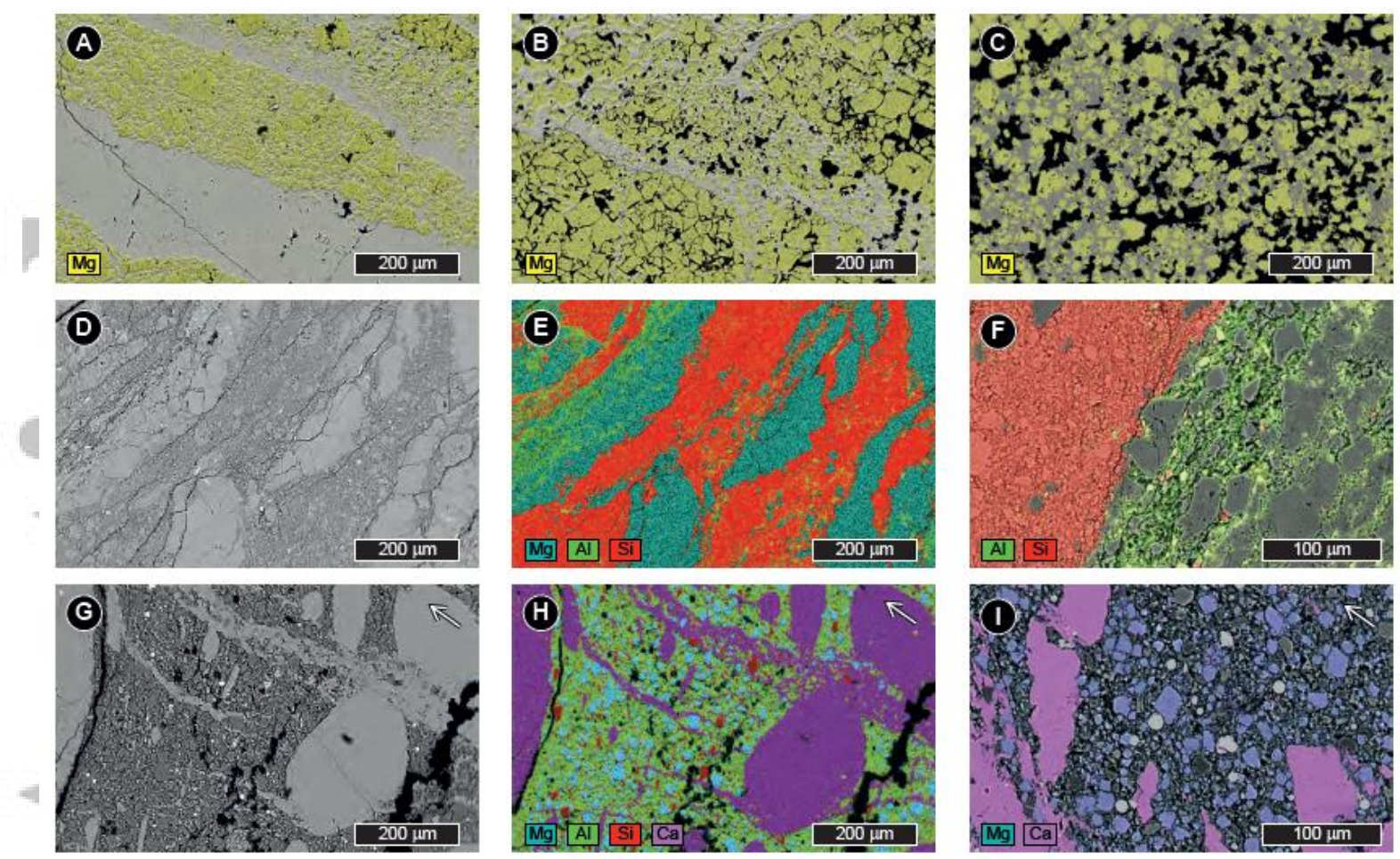

Figure 13. BSE images overlapped onto SEM-EDS qualitative compositional maps. (A-B-C) show calcite cement in the Bituminous dolostones of the footwall damage zone $(A-B)$ and in the fault core of the Monte Camicia Thrust (C); fracturing increases towards the fault core causing disaggregation of dolostones; calcite, occurring in discrete microfractures in A, becomes interparticle cement in C; secondary porosity increases. BSE (D) and map (E) of micro-crystalline silica bands overprinting tectonic stylolites in the hanging wall damage zone of the Vado di Ferruccio Thrust at Site VF1. (F) Detail of (D-E) illustrating a silica band parallel to- and reopening a pressure solution plane. BSE $(\mathrm{G})$ and map $(\mathrm{H})$ of tectonic stylolite in the Corniola of the Vado di Ferruccio Thrust footwall damage zone in Site VF3 showing Cal1 vein cutting through the stylolite and affected by partial dissolution, and idiotopic-E dolomite crystals occurring in the stylolite only. (I) Detail of the stylolite in $(\mathrm{G}-\mathrm{H})$ illustrating the idiotopic-E dolomite, which occurs only in the stylolite and is unaffected by dissolution. 

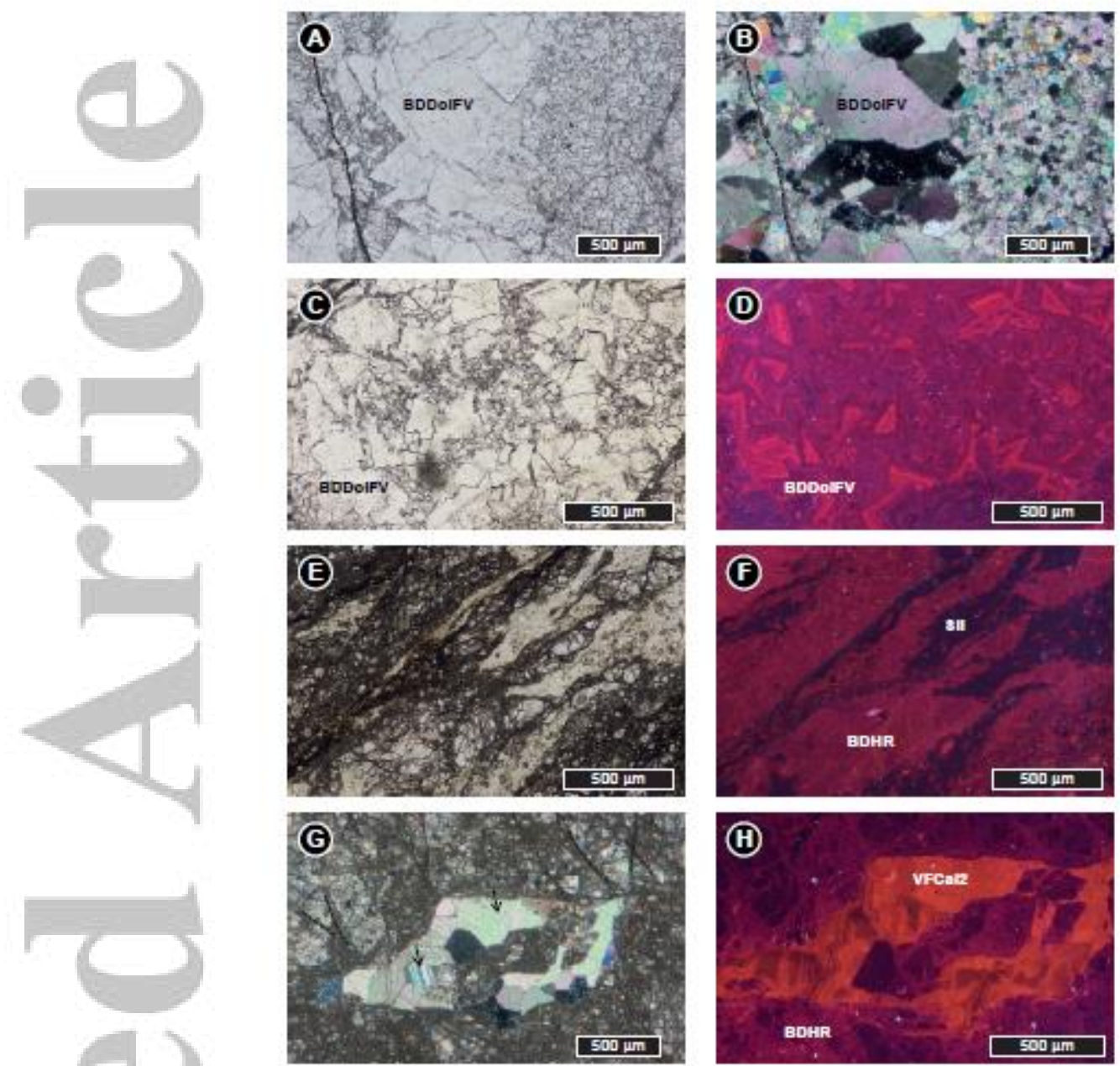

Figure 14. Petrography of the Bituminous dolostones in the hanging wall of the Vado di Ferruccio Thrust. (A) PPL and (B) XPL images showing fault-veins composed of coarse dolomite crystals, sometimes saddle-shaped, and chaotic dolomite breccia towards the median line. (C) PPL and (D) CL images of chaotic breccia; both dolomite host rock and cement are purple colored, except for the outer growth zones which display a red color. (E) PPL and (F) CL images of silica cemented fractures overprinting tectonic stylolite. (G) XPL and (H) CL images of extensional dilation jog cemented by equant calcite with orange-dull growth zones and interested by twinning.

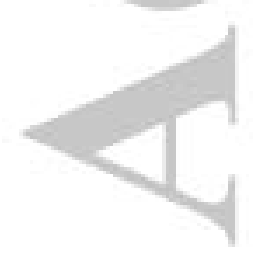



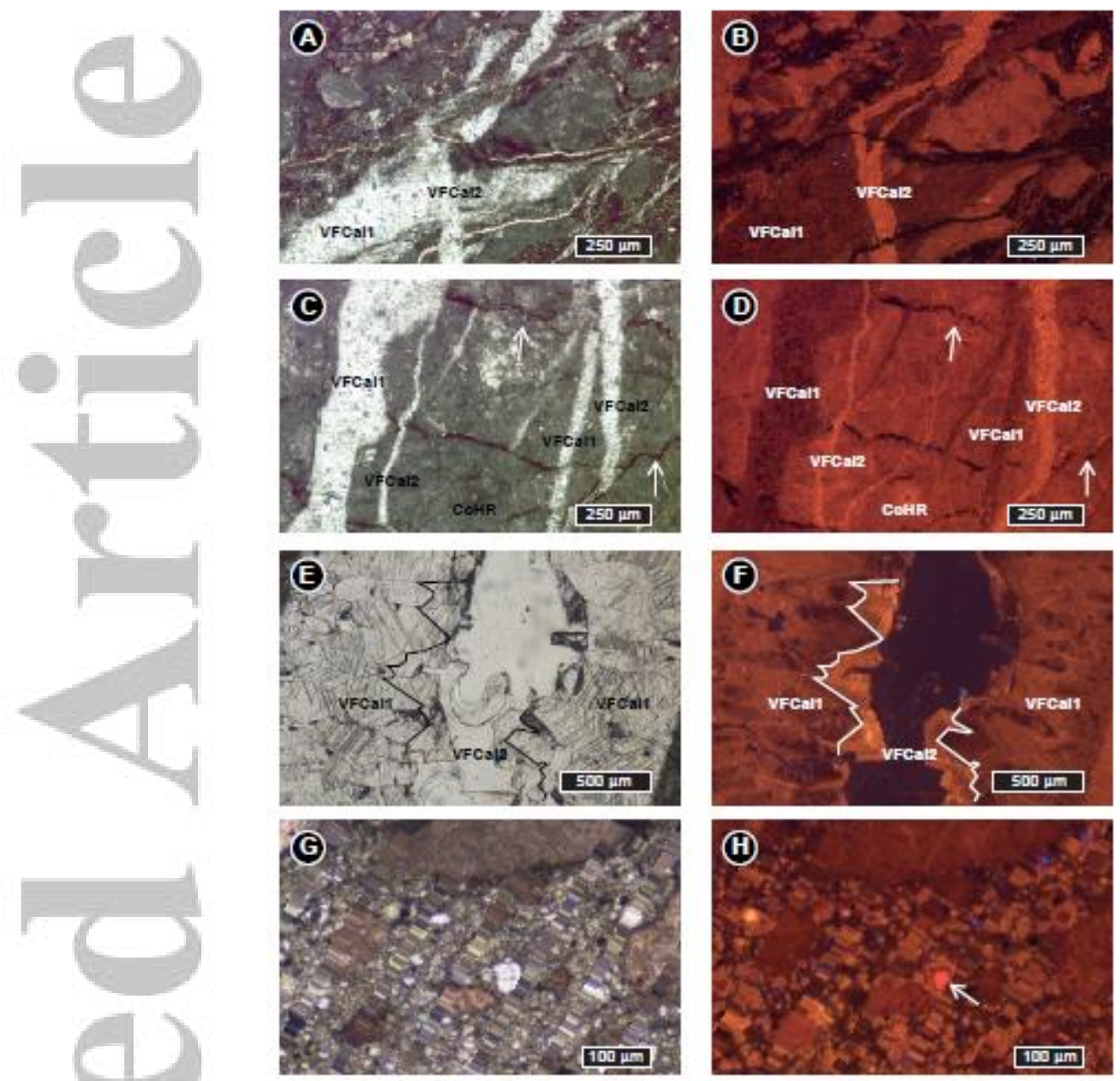

Figure 15. Petrography of the Corniola in the footwall damage zone of the Vado di Ferruccio Thrust. (A) PPL and (B) CL images of low-angle tectonic stylolites mutually crosscutting with VFCal1 veins and cut by VFCal2 veins. (C) PPL and (D) CL images showing high-angle, E-W striking veins cemented with VFCal1 and VFCal2 and crosscutting low-angle stylolites, indicated by white arrows; Cal1 is dissolved where it is crosscut by the stylolites. PPL (E) and (F) CL images showing high-angle, N-S striking vein cemented with VFCal1 and VFCal2 in optical continuity; twinning is more intense in VFCal1. (G) PPL and $(\mathrm{H}) \mathrm{CL}$ images showing idiotopic-E dolomite crystals in tectonic stylolites, characterized by cloudy pink cores and red-yellow growth zones. 

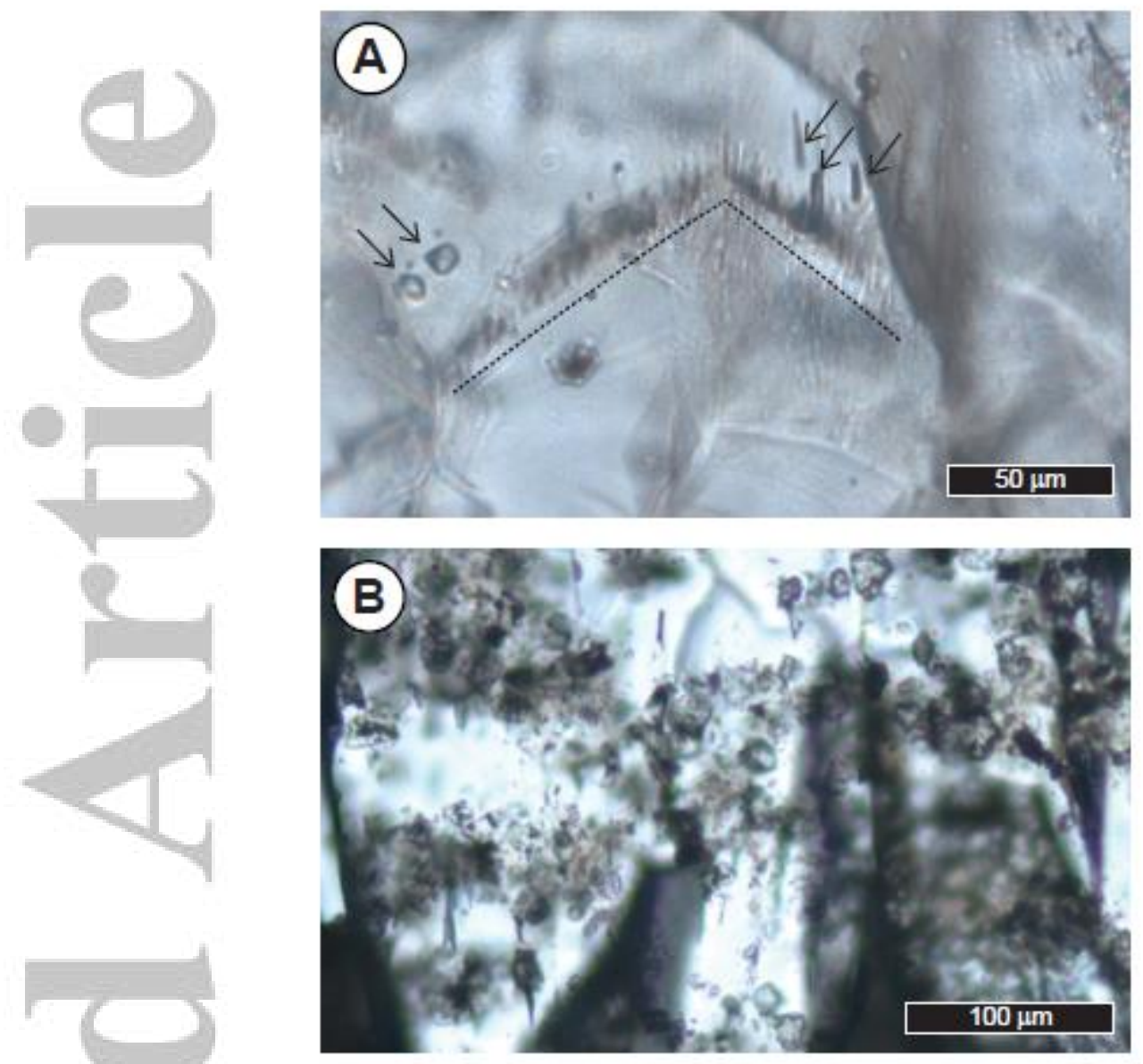

Figure 16. (A) PPL image of CFCalV calcite cement showing vertically elongated and negative crystal-shaped monophase fluid inclusions along and above a growth zone. (B) PPL image of CFCalP calcite cement displaying bands of vadose silt solid inclusions. 


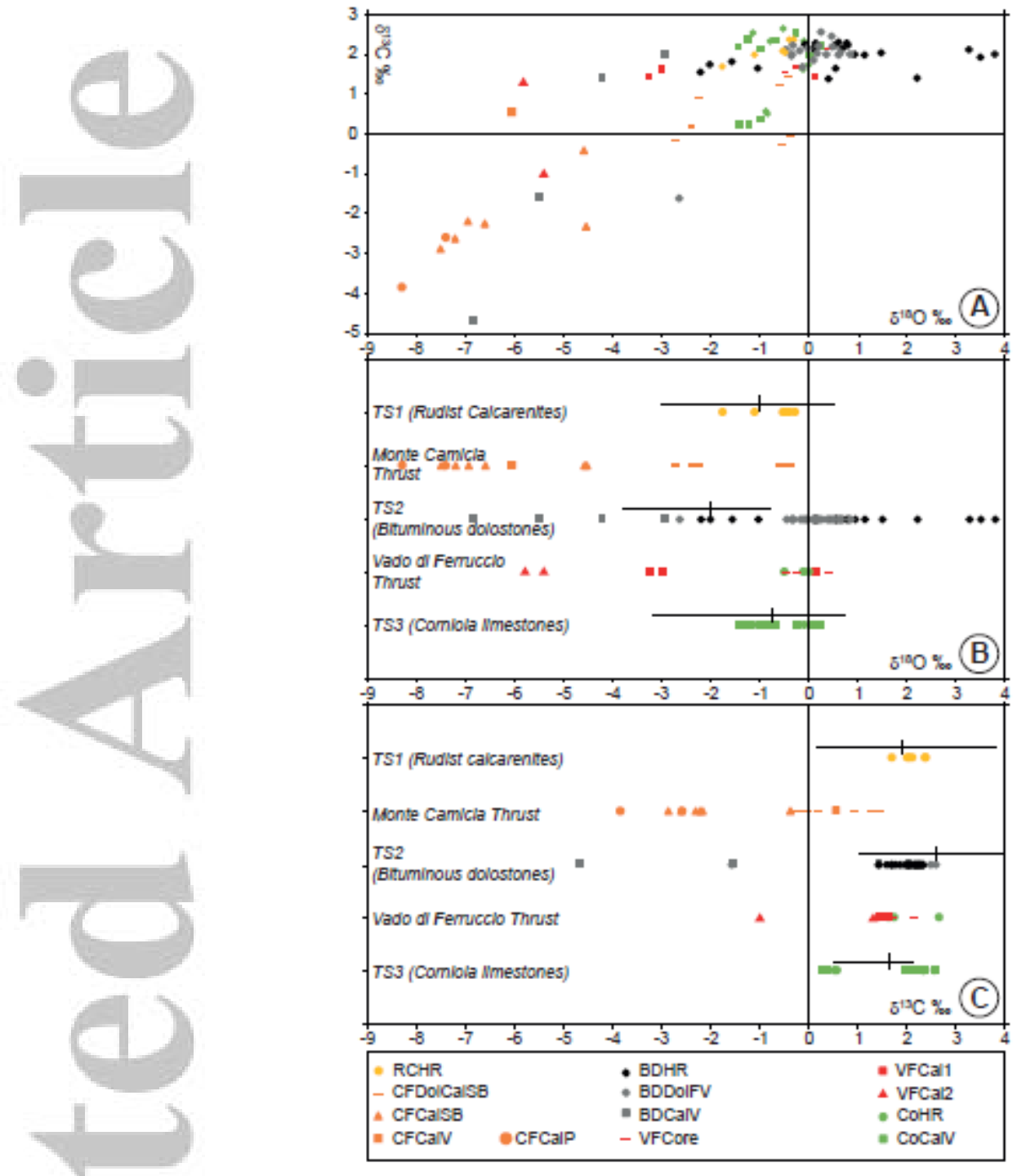

Figure 17. Oxygen and carbon stable isotopes data. (A) $\delta^{18} \mathrm{O}$ vs. $\delta^{13} \mathrm{C}$ plot; axes are in \%o VPDB. (B) $\delta^{18} \mathrm{O}$ vs. structural unit; black ticks and lines are average $\delta^{18} \mathrm{O} \%$ and $\pm 1 \sigma$ values of the seawater for the structural unit host rock age. (C) $\delta^{13} \mathrm{C} \%$ vs. structural unit black ticks and lines are average $\delta^{13} \mathrm{C} \%$ and $\pm 1 \sigma$ values of the seawater for the structural unit host rock age; seawater reference values from Veizer et al., 1999. 


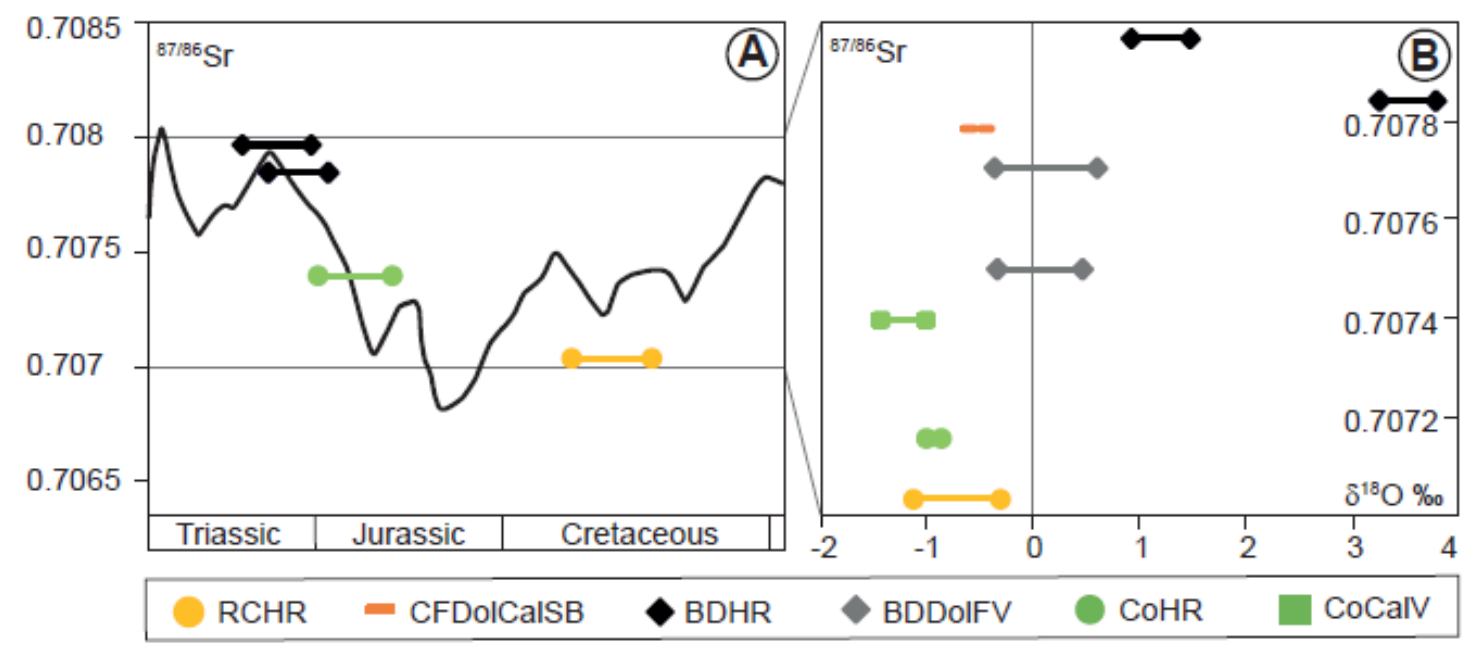

Figure 18. (A) Age vs. ${ }^{87 / 86} \mathrm{Sr}$ plot of host rock samples; black line represents strontium isotopes ratio of seawater. (B) $\delta^{18} \mathrm{O}$ vs. ${ }^{87 / 86} \mathrm{Sr}$ plot; $\delta^{18} \mathrm{O}$ in $\%$ V-PDB. See legend in Fig. 16; seawater reference values from McArthur et al., 2012. 


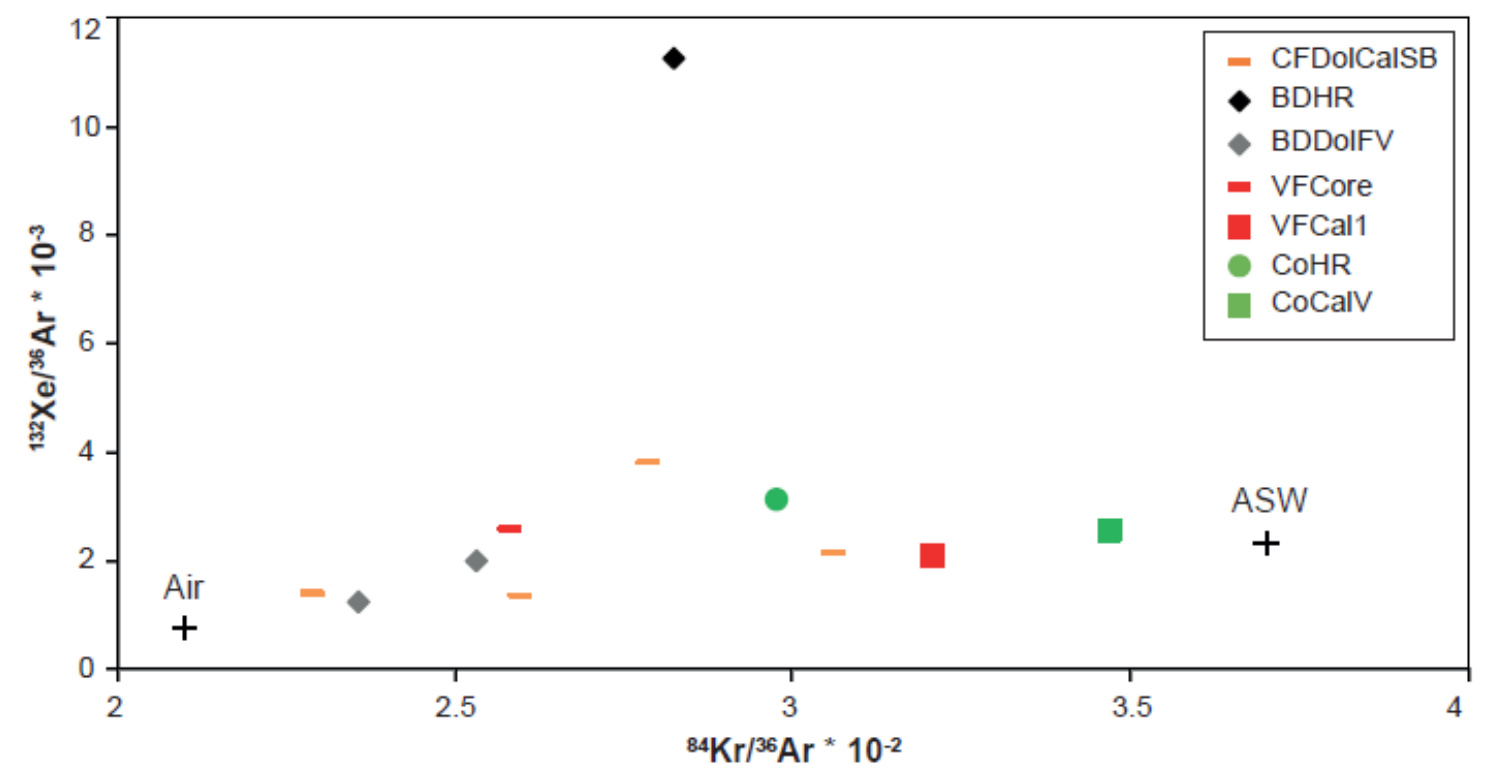

Figure 19. ${ }^{84} \mathrm{Kr} /{ }^{36} \mathrm{Ar}$ vs. ${ }^{132} \mathrm{Xe} /{ }^{36} \mathrm{Ar}$ plot of all analyzed samples; with the exception of Bituminous dolostones, samples lie on a mixing trend between Air and ASW (Air Saturated Water). 


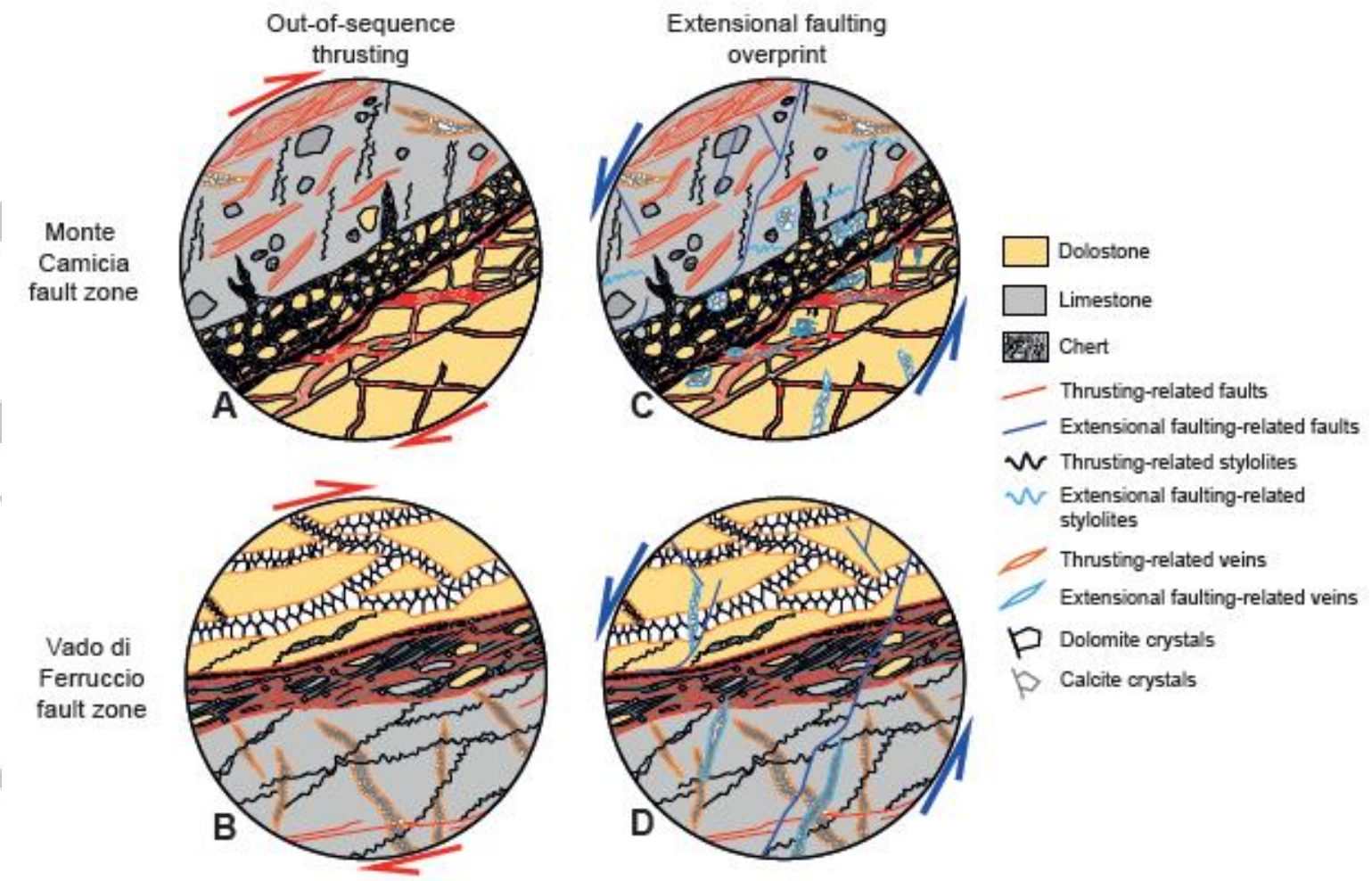

Figure 20. Conceptual structural diagenetic model of the studied fault zones. Fault zone architectures of the Monte Camicia (A) and Vado di Ferruccio (B) out-of-sequence thrusts during contractional deformation and their architectures after extensional deformation overprint in (C) and (D), respectively. 


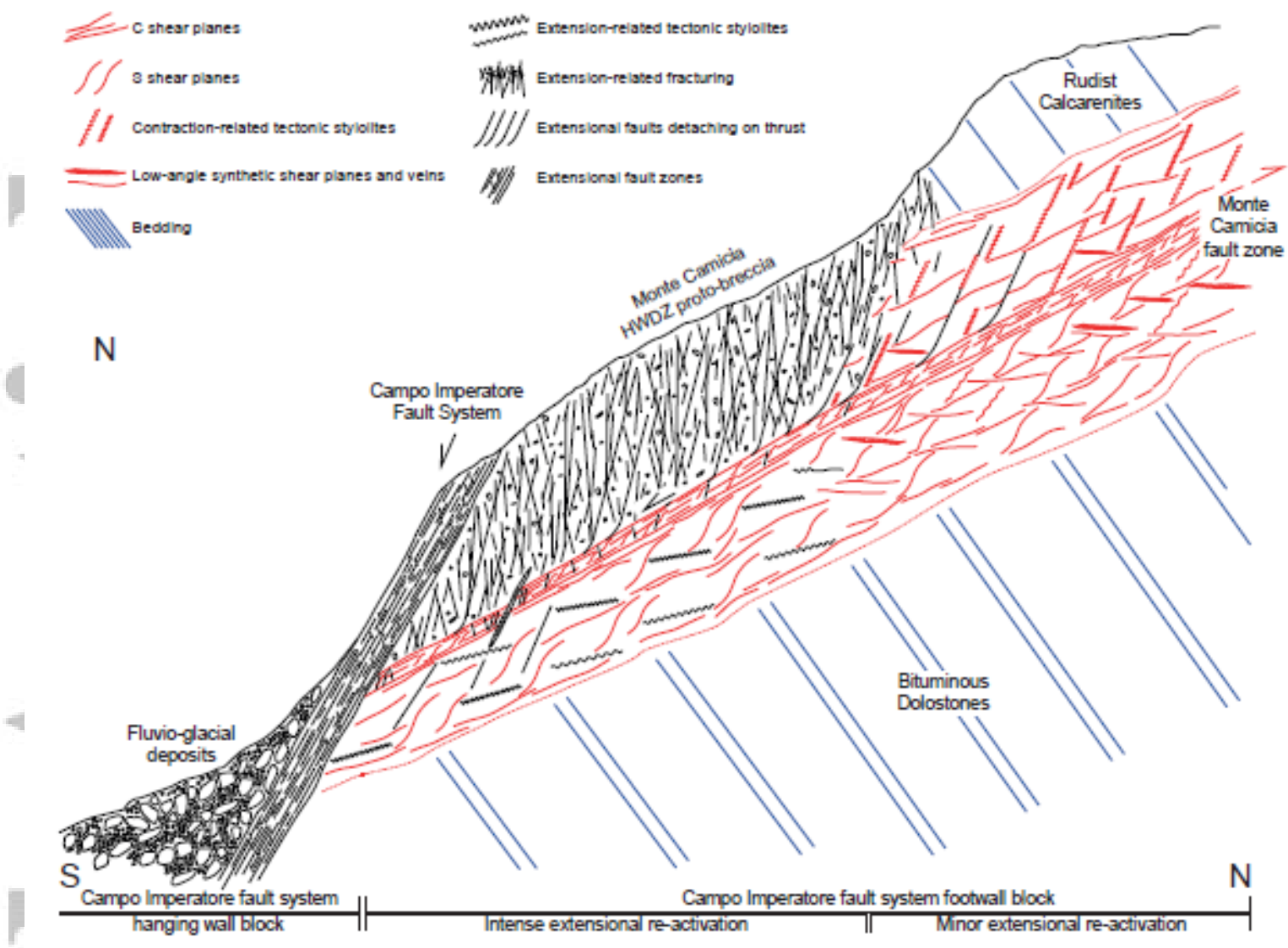

Figure 21. Conceptual structural sketch illustrating the Monte Camicia out-of-sequence thrust and the architectural modifications after extensional deformation overprint. 

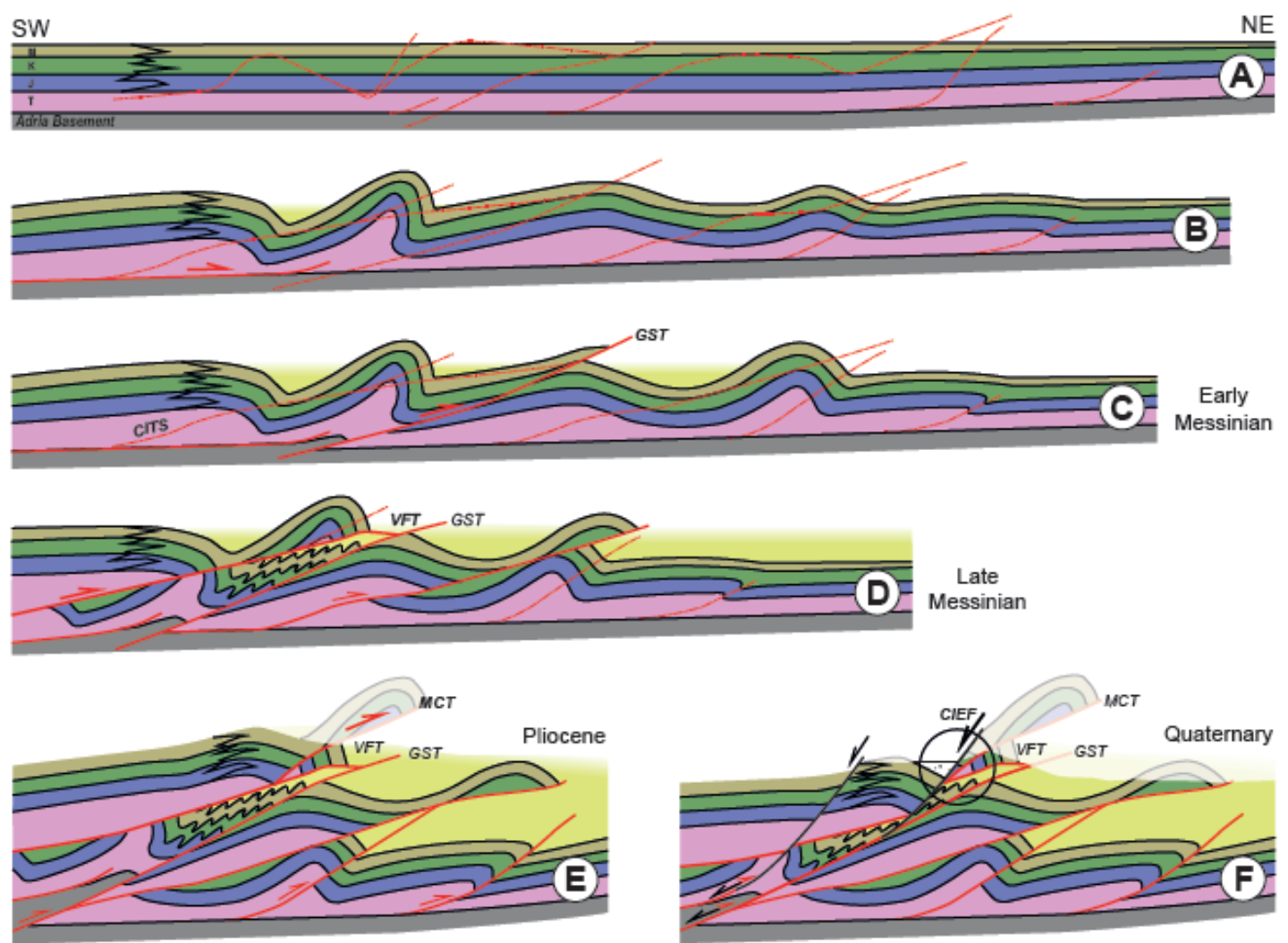

Figure 22. Conceptual tectonic evolutionary model proposed for the Gran Sasso Massif thrust stack. (A) Undeformed Adria passive margin succession; (B) Pre-Messinian early folding; (C) early Messinian; (D) late Messinian; (E) Pliocene; (F) Quaternary. Abbreviations are as follows: CITS for Campo Imperatore Thrust System; GST for Gran Sasso Thrust; VFT for Vado di Ferruccio Thrust; MCT for Monte Camicia Thrust; CIEF for Campo Imperatore Extensional Fault; modified from Ghisetti et al., 1993a. 
Table 1: Analyzed cement types and acronyms used in the text with their structural-geometrical location and timing.

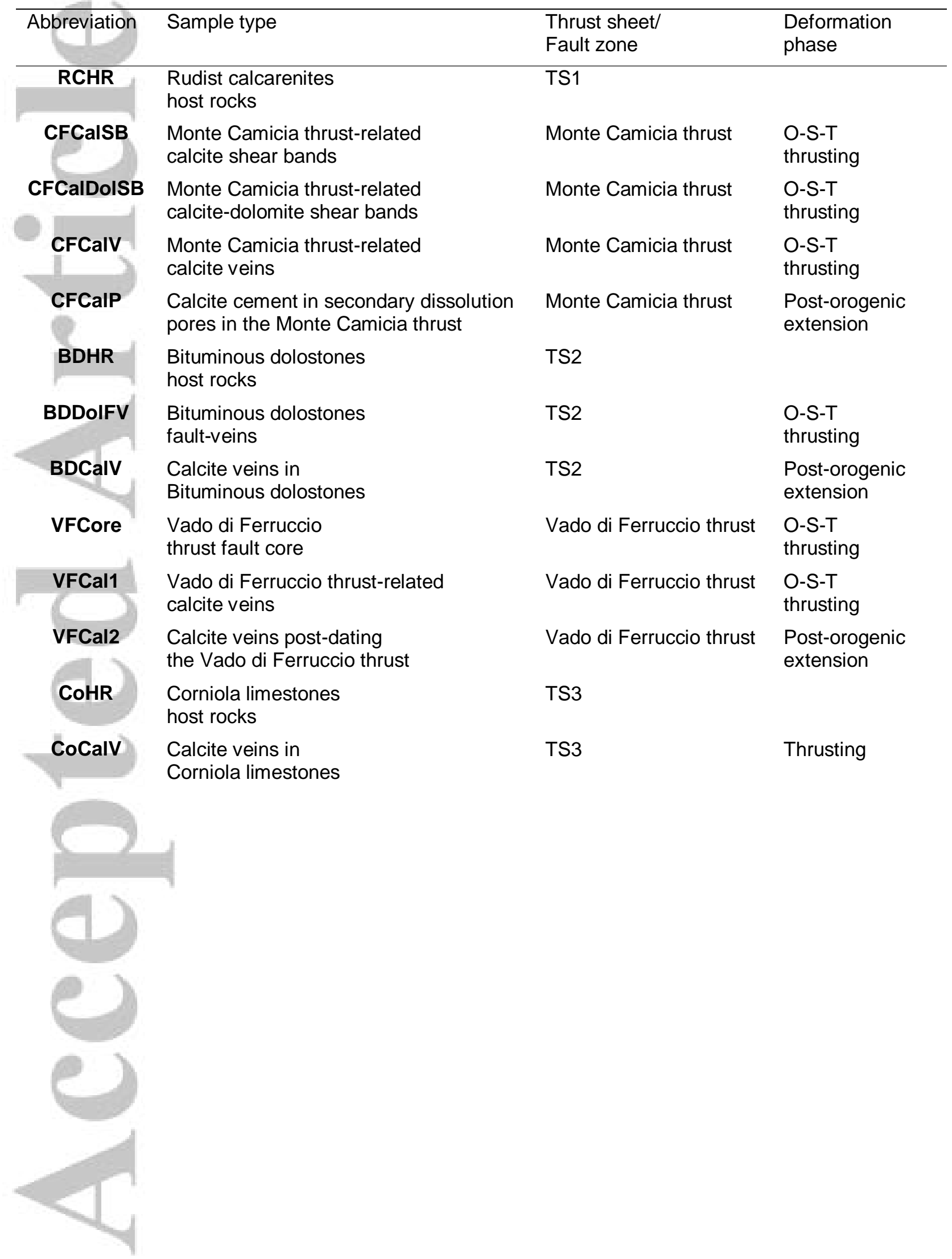


Table 2: Noble gas data. ${ }^{4} \mathrm{He}$ and ${ }^{36} \mathrm{Ar}$ abundances are in units of unless otherwise stated. Uncertainties are one standard deviation.

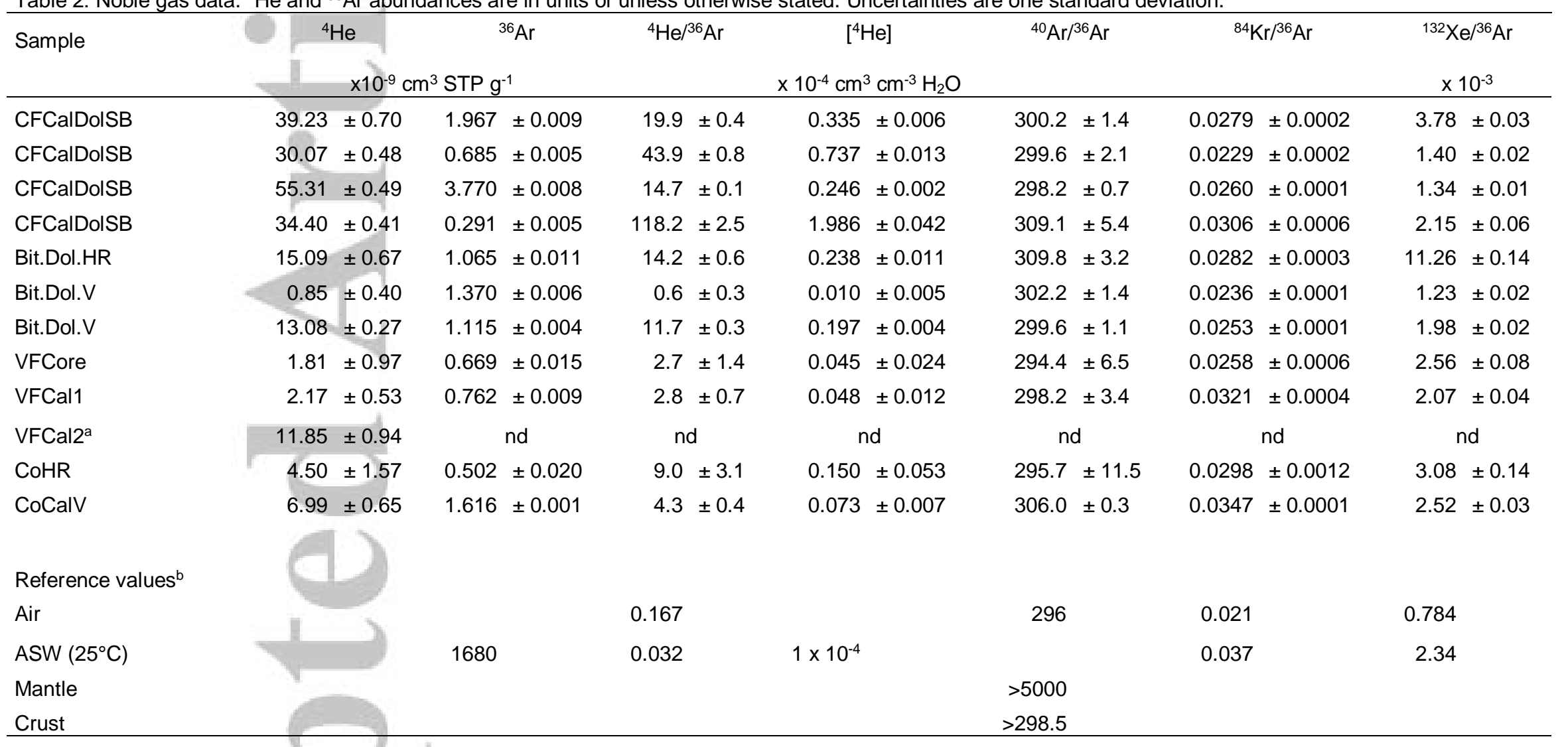

a For sample VFCal2 the Ar, Kr and Xe were pumped away during analysis and were not determined (nd).

b Characteristic compositions for air, air saturated water, mantle and crust (for data sources see Ballentine and Burnard, 2002; Ballentine et al., 2002). 